US Army Corps of Engineers ${ }_{\circledast}$ Engineer Research and Development Center

Center for the Advancement of Sustainability Innovations

\title{
Sustainable Carbon Dioxide Sequestration as Soil Carbon to Achieve Carbon Neutral Status for DoD Lands
}

Steven L. Larson, Ryan Busby, W. Andy Martin,

October 2017

Victor F. Medina, Peter Seman, Christopher A. Hiemstra,

Umakant Mishra and Tom Larson 
The U.S. Army Engineer Research and Development Center (ERDC) solves the nation's toughest engineering and environmental challenges. ERDC develops innovative solutions in civil and military engineering, geospatial sciences, water resources, and environmental sciences for the Army, the Department of Defense, civilian agencies, and our nation's public good. Find out more at www.erdc.usace.army.mil.

To search for other technical reports published by ERDC, visit the ERDC online library at http://acwc.sdp.sirsi.net/client/default. 


\section{Sustainable Carbon Dioxide Sequestration as Soil Carbon to Achieve Carbon Neutral Status for DoD Lands}

Steven L. Larson, W. Andy Martin, Victor F. Medina

Environmental Laboratory

U.S. Army Engineer Research and Development Center 3909 Halls Ferry Rd.

Vicksburg, MS 39180

Ryan Busby

Construction Engineering Research Laboratory

U.S. Army Engineer Research and Development Center 2902 Newmark Drive

Champaign, IL 61822

Christopher A. Hiemstra and Peter M. Seman

Cold Regions Research and Engineering Laboratory

U.S. Army Engineer Research and Development Center

72 Lyme Rd.

Hanover, NH 03755

Umakant Mishra

Argonne National Laboratory

9700 S. Cass Avenue

Lemont, IL 60439

Tom Larson

Larson Growth Industries

1921 Bearkling Place

Chapel Hill, NC 27517

Final report

Approved for public release; distribution is unlimited.

Prepared for U.S. Army Corps of Engineers

Washington, DC 20314-1000

Under Work Unit 33143 


\section{Abstract}

Sequestration of atmospheric carbon dioxide in soils is a promising alternative for mitigation of atmospheric carbon dioxide $\left(\mathrm{CO}_{2}\right)$. The Department of Defense (DoD) owns significant land and water resources which can be managed to offset emissions. Accounting for this, sequestration could help DoD reach carbon neutrality. Many activities the DoD engages in for sustainable land management and training sustainment are conducive to soil carbon storage without even considering this as an important component; however, carbon storage could be greatly enhanced by increased understanding of optimal storage conditions and by making slight adjustments to existing practices. Land management techniques may require adjustments to maximize carbon storage while maintaining training and environmental quality. In order to achieve this, data gaps for estimating carbon fluxes need to be addressed so that accurate measurements can be taken. Unknown aspects of carbon storage as it relates to plant-soil-soil microbe interactions need to be investigated to maximize carbon storage while maintaining land use requirements. Geo-engineering concepts require further refinement to increase carbon storage in soils. These knowledge gaps are not insurmountable and could be addressed through focused research to maximize and accurately quantify carbon storage on DoD lands.

DISCLAIMER: The contents of this report are not to be used for advertising, publication, or promotional purposes. Citation of trade names does not constitute an official endorsement or approval of the use of such commercial products. All product names and trademarks cited are the property of their respective owners. The findings of this report are not to be construed as an official Department of the Army position unless so designated by other authorized documents. 


\section{Contents}
Abstract
ii
Figures and Tables...
....v
Preface ......................................................................................................................................
Unit Conversion Factors ........................................................................................................................vii
Abbreviations ....................................................................................................................................... vili

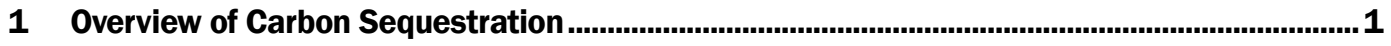

1.1 Carbon footprint of the DoD and impact on missions ....................................... 1

1.1.1 Executive Order 13693......................................................................................... 2

1.1.2 DoD approach to reducing carbon footprint........................................................ 2

1.2 Soil and the carbon cycle ................................................................................... 3

1.3 Soil sequestration of carbon .............................................................................. 4

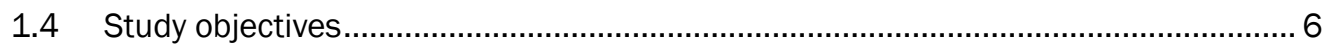

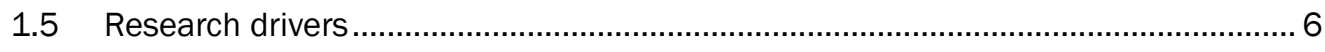

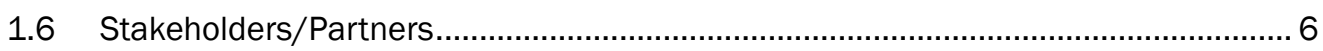

2 Measuring, Monitoring and Verifying Soil Carbon Change .................................................. 7

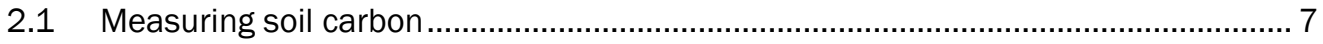

2.2 Monitoring soil carbon......................................................................................... 11

2.3 Verifying soil carbon models .......................................................................... 11

2.4 Research needs .......................................................................................... 13

3 Plant Processes Controlling Carbon Flux ............................................................................16

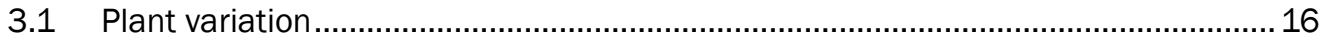

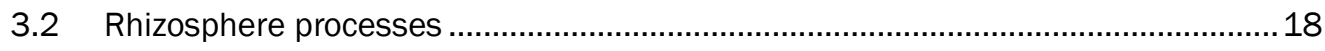

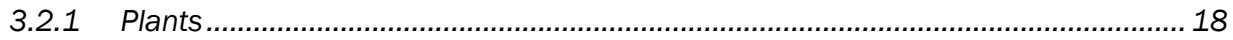

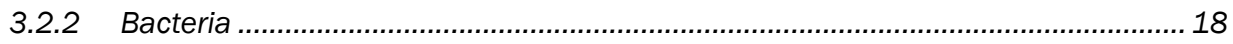

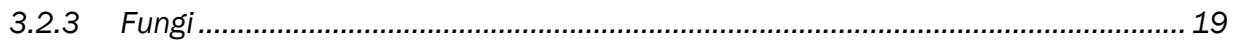

4 Land Management Effects on Soil Carbon Flux: Strategies to Maximize Carbon

Sequestration in Soil ...........................................................................................................................22

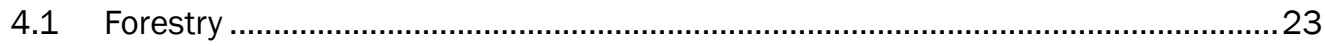

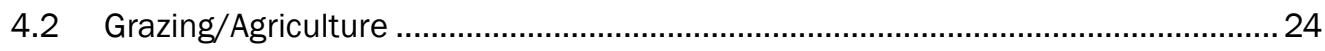

4.3 Prescribed Burning and Wildfire ....................................................................... 24

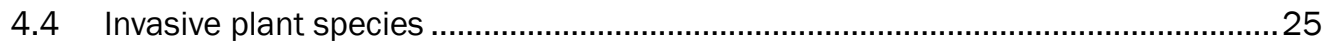

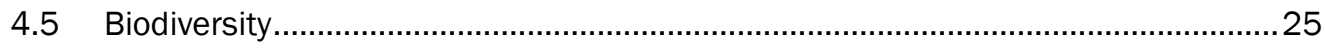

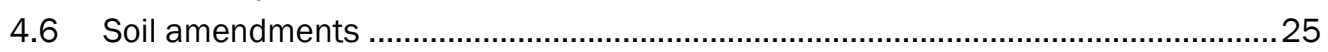

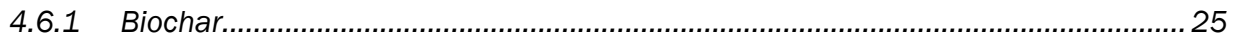

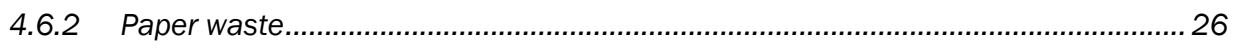

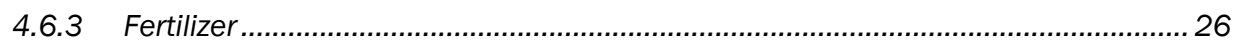

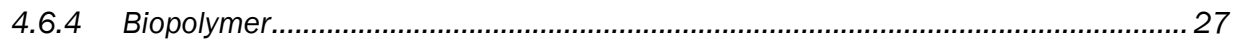




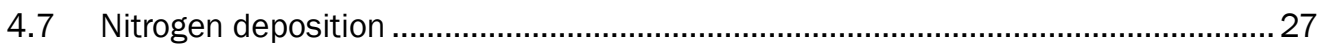

5 Wetland Management Effects on Soil Carbon Flux..............................................................29

6 Instigating and Maintaining Changes in Land Management that Promote Carbon Sequestration ...........................................................................................................................31

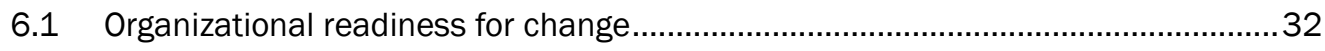

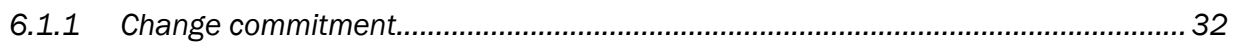

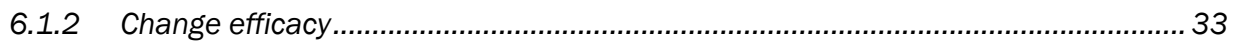

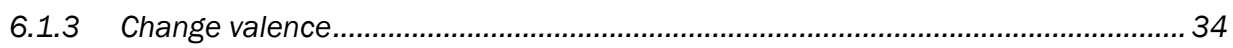

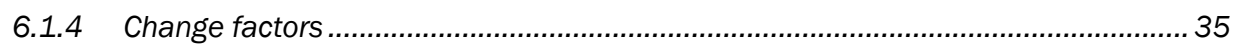

6.2 Organizational Readiness to Implement Change (ORIC) ..........................................35

6.3 Change for soil carbon sequestration and the DoD ...........................................35

7 Research Areas to Maximize Carbon Sequestration on DoD Lands ...................................37

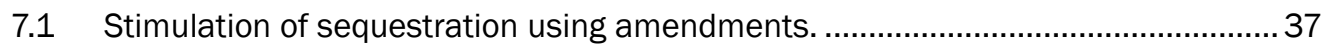

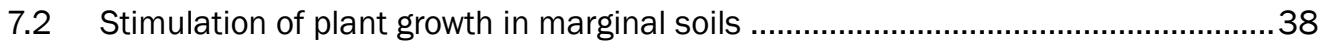

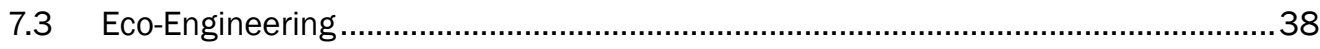

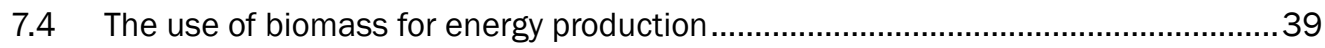

7.5 ERDC resources and funding vehicles .......................................................... 40

8 Conclusions.............................................................................................................................41

8.1 Is it possible to achieve carbon neutral status on DoD managed lands and

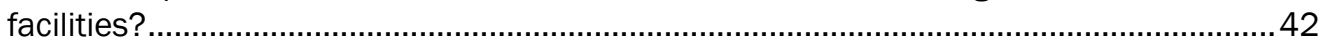

8.2 Could DoD facilities be useful for carbon banking? ........................................43

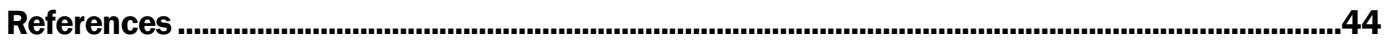

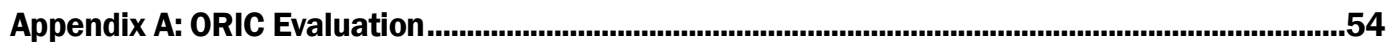

\section{Report Documentation Page}




\section{Figures and Tables}

\section{Figures}

Figure 1. Simplified diagram of the carbon cycle through the atmosphere, soil and water (Credit: Valerie Martin, Technical Education Research Center (TERC)).

Figure 2. Flux of carbon inputs and carbon sinks from 1880 to the present (Source: Canadell 2007, Global Carbon Project).

Figure 3. Soil organic carbon sensitivity to environmental change (Friedlingstein et al. 2014).

Figure 4. Estimating depth distribution of SOC stocks in Indiana when comparing top soil and sub soil concentrations

Figure 5. NEON sites and major DoD installations across the United States. Many DoD installations are in close proximity to NEON sites and occur on comparable ecosystems.

Figure 6. Land sinks for atmospheric carbon available on many DoD installations on facilities.

Figure 7. Examples of coastal vegetation: marshes (top left), mangrove stand (bottom left) and beach grass (right)

Figure 8. Factors involved in determining Organizational Readiness for Change (ORC).

\section{Tables}

Table 1. Paired NEON sites and DoD installations in close proximity with comparable ecosystems 15

Table 2. Estimates of carbon stocks in ecosystems (Adams 2016)...................................................16

Table 3. Root properties of ecosystems (Canadell et al. 1996; Jackson et al. 1996)........................17

Table 4. Estimates of root turnover by ecosystem (Lauenroth and Gill 2003)..................................18

Table 5. Mycorrhizal status of common North American trees. .......................................................20

Table 6. Summary of inputs into soil that either increase/decrease soil carbon. ..............................23

Table 7. Comparison of carbon sequestration characteristics of coastal vegetation and terrestrial forests. 


\section{Preface}

The work reported herein was conducted at laboratories throughout the Engineer Research and Development Center (ERDC), including the Environmental Laboratory (EL), the Cold Regions Research and Engineering Laboratory (CRREL), and the Construction Engineering Research Laboratory (CERL) under Work Unit 33143. Significant contributions were also made by participants from Argonne National Laboratory (ANL) of the Department of Energy (DoE). This project was approved and funding was supplied by the Center for the Advancement of Sustainability Innovations (CASI).

Review of this report was provided by Mr. Roy Wade and Ms. Deborah Felt of ERDC-EL.

At the time of publication of this report Dr. Ilker Adiguzel was Director, CERL, Dr. Joseph L. Corriveau was Director, CRREL, and Dr. Beth Fleming was Director, EL.

COL Bryan S. Green was the Commander of ERDC and Dr. David W. Pittman was the Director of ERDC. 


\section{Unit Conversion Factors}

\begin{tabular}{|c|c|c|}
\hline Multiply & By & To Obtain \\
\hline acres & $4,046.873$ & square meters \\
\hline cubic feet & 0.02831685 & cubic meters \\
\hline cubic inches & $1.6387064 \mathrm{E}-05$ & cubic meters \\
\hline cubic yards & 0.7645549 & cubic meters \\
\hline degrees Fahrenheit & $(\mathrm{F}-32) / 1.8$ & degrees Celsius \\
\hline feet & 0.3048 & meters \\
\hline gallons (U.S. liquid) & 3.785412 E-03 & cubic meters \\
\hline hectares & $1.0 \mathrm{E}+04$ & square meters \\
\hline inches & 0.0254 & meters \\
\hline microns & $1.0 \mathrm{E}-06$ & meters \\
\hline miles (U.S. statute) & $1,609.347$ & meters \\
\hline ounces (mass) & 0.02834952 & kilograms \\
\hline ounces (U.S. fluid) & $2.957353 \mathrm{E}-05$ & cubic meters \\
\hline pints (U.S. liquid) & 4.73176 E-04 & cubic meters \\
\hline pints (U.S. liquid) & 0.473176 & liters \\
\hline pounds (mass) & 0.45359237 & kilograms \\
\hline pounds (mass) per cubic foot & 16.01846 & kilograms per cubic meter \\
\hline pounds (mass) per cubic inch & $2.757990 \mathrm{E}+04$ & kilograms per cubic meter \\
\hline pounds (mass) per square foot & 4.882428 & kilograms per square meter \\
\hline pounds (mass) per square yard & 0.542492 & kilograms per square meter \\
\hline quarts (U.S. liquid) & $9.463529 \mathrm{E}-04$ & cubic meters \\
\hline square feet & 0.09290304 & square meters \\
\hline square inches & $6.4516 \mathrm{E}-04$ & square meters \\
\hline square miles & $2.589998 \mathrm{E}+06$ & square meters \\
\hline square yards & 0.8361274 & square meters \\
\hline tons (long) per cubic yard & $1,328.939$ & kilograms per cubic meter \\
\hline tons ( 2,000 pounds, mass) & 907.1847 & kilograms \\
\hline tons $(2,000$ pounds, mass) per square foot & $9,764.856$ & kilograms per square meter \\
\hline yards & 0.9144 & meters \\
\hline
\end{tabular}




\section{Abbreviations}

$\begin{array}{ll}\text { AMF } & \text { Arbuscular mycorrhizal fungi } \\ \text { CASI } & \text { Center for the Advancement of Sustainable Innovation } \\ \text { CERL } & \text { Construction Engineering Research Laboratory } \\ \text { CO2 } & \text { Carbon dioxide } \\ \text { CPR } & \text { Climate Preparedness and Resilience } \\ \text { CRREL } & \text { Cold Regions Research and Engineering Laboratory } \\ \text { DoA } & \text { Department of the Army } \\ \text { DoD } & \text { Department of Defense } \\ \text { DoE } & \text { Department of Energy } \\ \text { EL } & \text { Environmental Laboratory } \\ \text { EMF } & \text { Ectomycorrhizal fungi } \\ \text { EO } & \text { Executive Order } \\ \text { EPS } & \text { Exopolysaccharide } \\ \text { ERDC } & \text { Engineer Research and Development Center } \\ \text { ESM } & \text { Earth System Models } \\ \text { GAO } & \text { General Accounting Office } \\ \text { GHG } & \text { Greenhouse Gases } \\ \text { IPCC } & \text { Intergovernmental Panel on Climate Change } \\ \text { LULC } & \text { Land Use-Land Cover } \\ \text { MODIS } & \text { Moderate Resolution Imaging Spectroradiometer } \\ \text { NBCD } & \text { National Biomass and Carbon Dataset } \\ \text { NDVI } & \text { Normalized Difference Vegetation Index } \\ \text { NEON } & \text { National Ecological Observatory Network } \\ \text { NLCD } & \text { National Land Cover Database } \\ \text { NRCS } & \text { Natural Resources Conservation Service } \\ \text { NSF } & \text { National Science Foundation } \\ \text { ORC } & \text { Organizational Readiness to Change } \\ \text { ORIC } & \text { Organizational Readiness to Implement Change } \\ \text { PAR } & \text { Photosynthetically Active Radiation } \\ \text { RaCA } & \text { Rapid Carbon Assessment } \\ \text { SEIA } & \text { Solar Energy Industries Association } \\ & \end{array}$


SOC Soil Organic Carbon

SSURGO Soil Survey Geographic Database

USACE U.S. Army Corps of Engineers

USDA United States Department of Agriculture 


\section{Overview of Carbon Sequestration}

Federal agencies, including the Department of Defense (DoD), are accounting for greenhouse gas emissions. However, effects of landscape and land use management on soil emissions and soil sequestration (ecosystem services) are not yet considered completely in calculations towards meeting emissions reduction goals (Council on Environmental Quality, Federal Greenhouse Gas Accounting and Reporting Guidance 2016) and scientifically defensible estimates are lacking in many of these areas. The DoD is a major landowner and end-user of naturally vegetated lands with significant net carbon sequestration potential. Carbon offsets due to sequestration on these lands could be a major source of compliance for future requirements, if and when inclusion is allowed. Use of DoD land for sequestration could also contribute to the required goal of achieving "carbon neutral" status for DoD facilities and installations. While a significant body of literature and products (including predictive models) exist for carbon accounting, due to the highly variable and unique nature of DoD lands and land uses, the applicability of these models for DoD lands is not known. Also, land end-users often express reluctance to accept changes in soil and wetlands management strategies without supporting information due to potential large capital investments that may be required for the implementation of new land management techniques. Moreover, most accounting procedures only consider snapshot one-time estimates without estimating natural or disturbance modulated variability over time.

\subsection{Carbon footprint of the DoD and impact on missions}

The DoD is the largest energy using entity in the world (Solar Energy Industries Association (SEIA) 2013). Most of the DoD's energy comes from fossil fuels. In 2011, it was estimated that the DoD consumed over 5 billion gallons of oil. Consequently, the DoD is also one of the most important sources of carbon emissions to the world's atmosphere, with $\mathrm{CO}_{2}$ emissions of 52.2 metric tons as estimated in 2010 (Walker 2011).

Carbon emissions affect DoD missions primarily because they relate to energy consumption and fossil fuel use. Lowering carbon emissions can be equated to lower fuel consumption, reducing costs, and making DoD entities less susceptible to supply issues associated with fossil fuels. 
Carbon footprint can also affect DoD emissions by affecting global climate change. In many cases, climate change is causing, and is expected to further cause, increased frequency of drought and low precipitation. Water supply issues are contributing to worldwide conflict and may also affect water supply issues during military operations (CNA 2014). Climate change is also resulting in an increase of intensity of large storms. Climate change has already been linked to a 3 inch rise in sea level, which contributes to an increase in flood events worldwide (AECOM 2013), including recently in south Florida. In one case, 31 communities in Alaska are in danger of inundation and may have to be relocated (General Accounting Office (GAO) 2009). The costs of relocation or improvements are estimated by the U.S. Army Corps of Engineers (USACE) to range from $\$ 150$ to $\$ 250$ million per community (Herrman 2015; USACE 2006). Climate change is expected to affect wildlife habitat on Army installations, including those of threatened and endangered species (Lozar et al. 2011). It may also increase the frequency and intensity of Harmful Algal Blooms in USACE reservoirs (Medina et al. 2016) as well as potentially affecting potable water supplies for Army installations.

\subsubsection{Executive Order 13693}

In 2013, the Executive Office of the President of the United States released a Climate Action Plan, which identified climate change as a critical National issue and committed the United States to reducing its carbon footprint (Executive Office of the President 2013). On 19 March 2015, President Barack Obama issued Executive Order (EO) 13693, Planning for Federal Sustainability in the Next Decade (https://www.whitehouse.gov/the-pressoffice/2015/03/19/executive-order-planning-federal-sustainability-next-decade). This document focuses on energy sustainability and greenhouse gas emission reductions. The EO set a goal of $40 \%$ reduction in greenhouse gases by Federal entities within 10 years.

\subsubsection{DoD approach to reducing carbon footprint}

The DoD has already begun efforts to reduce its carbon footprint. Currently, these efforts fall under one of the following three options:

reduction of fuel use due to changes in human behavior (see memorandum from Under Secretary of Defense urging Energy Awareness

(http://img.docstoccdn.com/thumb/orig/42642773.png)), reduction of fuel use due to technological controls (for example, use of more efficient exterior lighting (Department of the Army (DoA) 2010), and reduction of fuel use due to 
alternative energy, such as the use of solar energy (SEIA 2013). These methods have tremendous value and should definitely be encouraged and developed. However, the easily accomplished opportunities using these approaches has already been implemented in many cases. Further, these approaches cannot by themselves result in an installation that emits zero net carbon - a carbon neutral installation. This report proposes to explore carbon sequestration using the vast lands owned by the DoD. This approach could greatly decrease the carbon footprint for the DoD, and may legitimately open up opportunities for carbon neutral or even carbon negative installations.

\subsection{Soil and the carbon cycle}

Carbon is a naturally-occurring element that is one of the key building blocks of all living things on Earth. Carbon is exchanged by photosynthesis, respiration, digestion, and decomposition. Carbon emissions refers to carbon that is released to the atmosphere by any process. It is the flux of carbon into and out of the environment that is the carbon cycle (Lal 2001).

Some of the carbon on earth is stored over long periods of time. The places where carbon is stored are called sinks, and include the deep ocean, rocks, fossil fuel deposits, soils, sediment at the bottom of lakes, reservoirs and wetlands; and woody vegetation (such as forested areas). Carbon storage is not permanent. For example, erosion can transport carbon from top soils by stream flow to reservoirs, where that carbon can become trapped in a new sink; the sediment at the bottom of the reservoir. A source is any living organism, or sink, that releases carbon to the active cycle; anything that accumulates and stores carbon can be a sink. Many critical components of the carbon cycle (such as forests) can serve as both sources (e.g., when burned) or sinks (when growing) for carbon, depending upon its state. Fossil fuels (coal, oil, and gas) are formed over long periods of time, and represent the slow, steady removal of a great deal of carbon from earth's atmosphere over millennia (sink). The burning of fossil fuels constitutes a very rapid release of this carbon over a handful of decades (source). At the same time, some important carbon sinks (such as tropical rainforests and coastal wetlands) have been degraded through development. Carbon is currently being added to the atmosphere faster than it can be absorbed by sinks. 
The natural carbon cycle has remained relatively stable for thousands of years. Carbon enters the atmosphere as carbon dioxide $\left(\mathrm{CO}_{2}\right)$ from respiration and combustion processes. The atmospheric $\mathrm{CO}_{2}$ is adsorbed by plants to make carbohydrates through photosynthesis. Plants grow through development of root systems and aboveground biomass. At the end of the growing season, these plant parts decay and are assimilated into the soil as organic matter (another form of carbon). The dead organic matter is food for microbes and fungi which respire some of the carbon as $\mathrm{CO}_{2}$ back into the atmosphere. However, not all the carbon used by the microbes and fungi is respired; decomposition of organic matter can also result in the production of humic material. Humic material stores carbon in the soil on a geologic time scale. A summary of the carbon cycle is presented in Figure 1.

Figure 1. Simplified diagram of the carbon cycle through the atmosphere, soil and water (Credit: Valerie Martin, Technical Education Research Center (TERC)).

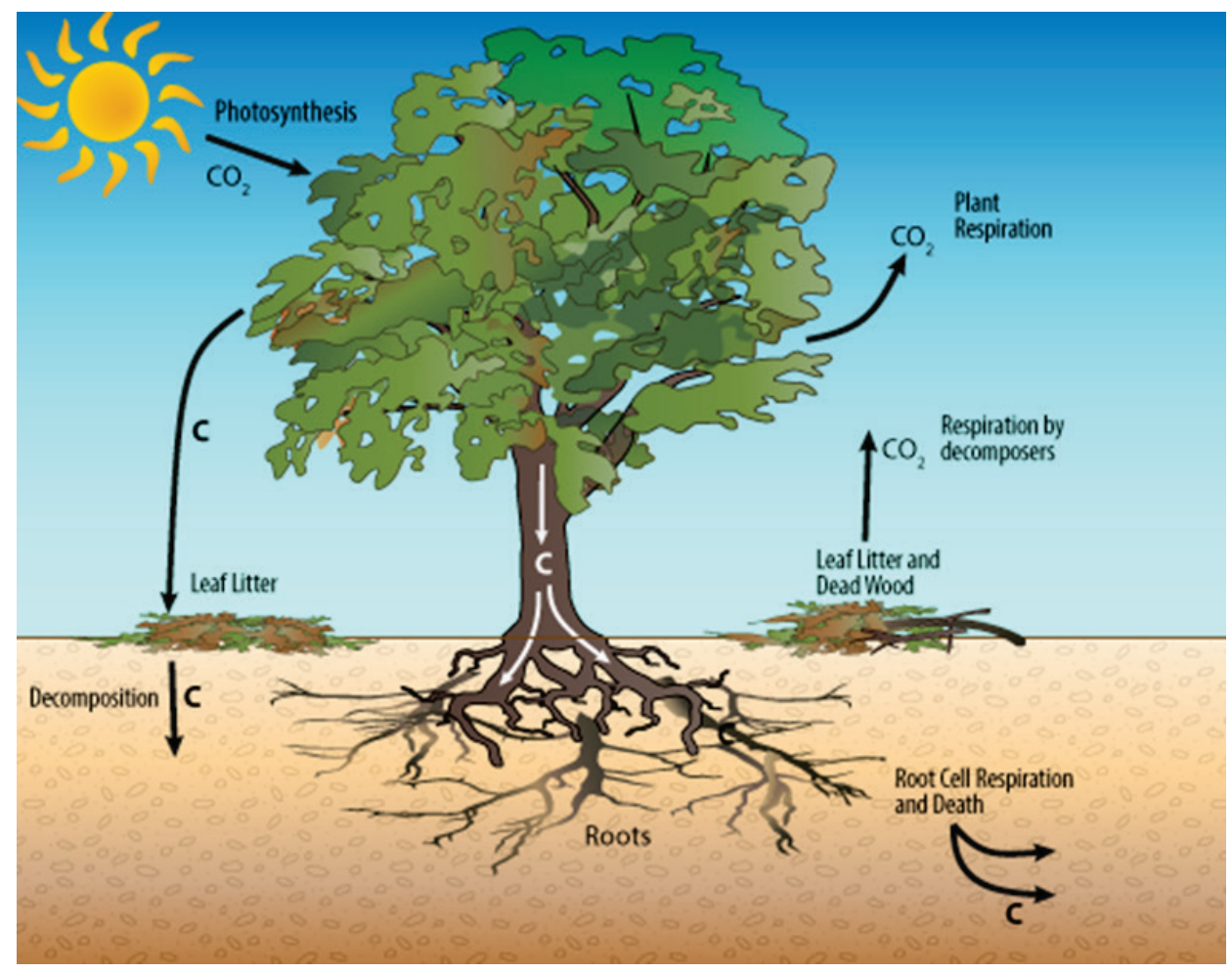

\subsection{Soil sequestration of carbon}

Carbon sequestration is the process of extracting carbon from the atmosphere and the active part of the carbon cycle and placing it in long term storage in natural or artificial carbon sinks. At the global scale, natural carbon sinks include the absorption of $\mathrm{CO}_{2}$ by oceans and other 
waterways through physiochemical and biological processes, photosynthesis by vegetation and sequestration of carbon in soil organic matter. This report addresses carbon sequestration on DoD lands and facilities within the continental U.S. It is therefore concerned with the terrestrial and aquatic portions of the carbon cycle. The major sinks of interest include soils, ecosystems, and reservoirs/lakes and wetlands (freshwater and marine), with an eye towards accounting for the amount of carbon that is currently sequestered in these sinks, and how much more could be sequestered in the future through changes in land management or facility use.

Land is a critical sink for carbon (Figure 2). The historical maximum concentration has been 2.8 trillion tons of organic carbon. The present concentration is 2.3 trillion tons. Carbon released from soil and not replaced is estimated to be between $200-500$ billion tons. The hypothesis presented in this paper is that the soil carbon sink can be increased, and increased quickly. As the soil becomes a better carbon sink, the $\mathrm{CO}_{2}$ levels in the atmosphere will decrease. Carbon in the ocean will also decrease as it equilibrates with the lower atmospheric $\mathrm{CO}_{2}$.

Figure 2. Flux of carbon inputs and carbon sinks from 1880 to the present (Source: Canadell 2007, Global Carbon Project).

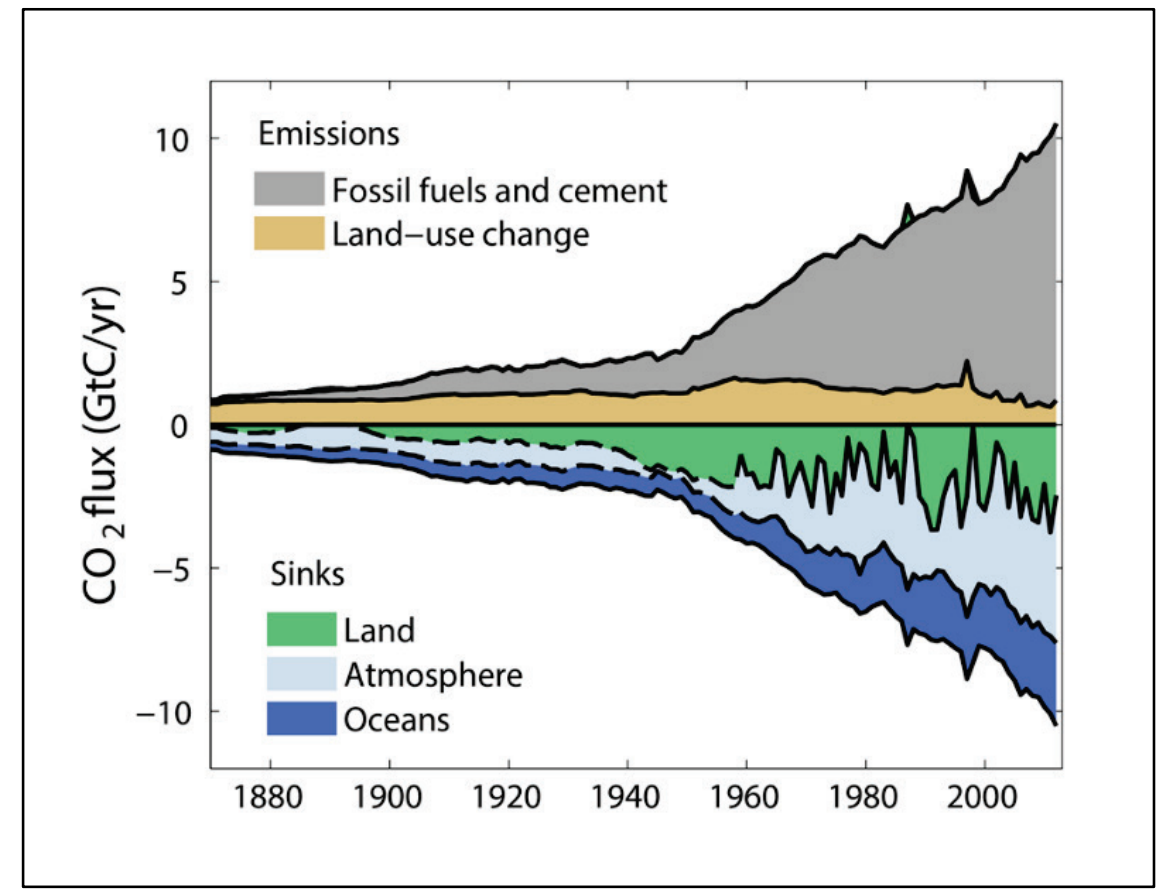




\subsection{Study objectives}

To better address EO 13693 directing all DoD installations to achieve carbon neutral status, and also meet the requirements of freshwater and coastal wetlands regulations, this Center for the Advancement of Sustainability Innovation (CASI) white paper will elucidate challenges and identify the data gaps to reducing atmospheric $\mathrm{CO}_{2}$ levels through sequestration of carbon in natural soil sinks. This paper will explore the state of knowledge regarding carbon fluxes in the environment as they pertain to specific activities and requirements on DoD lands. Specific research areas will be identified to improve predictive models. Activities and requirements that influence carbon flux on DoD lands will be compared to existing general sequestration models to determine what differences exist and to what extent they differ. Also, investigative approaches to increasing carbon sequestration in soil that will engage land users, and clarify management and environmental drivers will be explored.

\subsection{Research drivers}

- EO 13693 (2015) directing reductions of carbon, with an overall goal of 40\% reduction from 2008 levels by 2025 .

- U.S. Army Net Zero Energy - Net Zero Energy is a goal for Army Installations to attempt to achieve a Net Zero energy status. This includes energy reductions, which impact carbon emissions. It can also involve the use of biomass to generate energy, which could be included in a sequestration program.

\subsection{Stakeholders/Partners}

It is important to identify the potential stakeholders within the DoD as the specific needs of each group will differ as they attempt to achieve carbon neutral status for the lands under their stewardship. That is, managers of active firing ranges will have different concerns from those of the DoD industrial base, or from those of primarily research facilities, or wetlands under USACE management. All DoD, generally, and USACE, particularly, are considered stakeholders in the development of techniques to enhance carbon sequestration in soil. 


\section{Measuring, Monitoring and Verifying Soil Carbon Change}

Re-carbonization of the terrestrial biosphere by restoring carbon pools in Earth's soils, trees, and wetlands is an important step toward both mitigating and adapting to abrupt climate change. Carbon sequestration in terrestrial ecosystems has numerous co-benefits, such as the following:

- increasing net primary productivity

- advancing food security

- improving the quality and quantity of water resources

- enhancing biodiversity (Lal 2010).

Under the United Nations Framework Convention on Climate Change, land management activities that lead to change in carbon concentration of soils can be accounted as a carbon sink, or source, in generating and reporting greenhouse gas (GHG) inventories and using it for payment for ecosystem services through trading carbon credits (Intergovernmental Panel on Climate Change (IPCC) 2013). However, in order to have a successful carbon credit exchange and banking system, changes in carbon concentration of soils needs to be quantified and verifiable.

\subsection{Measuring soil carbon}

Measurements of soil carbon concentration in a laboratory have been conducted since the 1860 s. The principal objective of such measurements has been the evaluation of soil fertility in the vegetation root zone as influenced by agronomic practices such as tillage, crop rotations, and fertilization. Both wet and dry combustion methods are used for these kinds of measurements. Conventional units of reporting soil organic carbon (SOC) and total carbon concentrations are percentages or gramper-kilogram measurements on a dry-weight basis. Uncertainties in the data on measurements of carbon concentrations are caused by spatial variability in soil properties (e.g., soil bulk density).

In the context of evaluating soil carbon sink capacity of managed ecosystems, the objective is to quantify management-induced changes in the total SOC pool (Pg carbon per ha) and compute the rate of change with reference to baseline (Pg carbon per ha per year) over a landscape, farm, watershed, or regional scale (Lal 2010). Several broad field measurements 
have been performed such as that reported for the entire lower United States by the Natural Resources Conservation Service, National Soil Survey Center (West et al. 2013). The Rapid Carbon Assessment (RaCA) project sampled for SOC and other soil variables, collecting 144,833 samples from the upper meter of 32,084 soil profiles at 6,017 randomly selected locations. Measurements were taken of both organic and inorganic carbon by visible and near infrared spectroscopy. Sites from the National Resources Inventory were used as the basis for random selection of sample sites stratified by soil group within RaCA region and by land use-land cover (LULC) classification within soil group. The RaCA regions were identical to the areas of responsibility of the Natural Resources Conservation Service (NRCS) Major Land Resource Area Regional Offices at the time of sampling. At each sample site, soil morphology and landscape characteristics were described and some limited information regarding vegetation and agricultural management was collected.

Land/soil carbon sensitivity to environmental change is a dominant source of uncertainty in predicting carbon-climate feedbacks (Burke et al. 2012; Friedlingstein et al. 2014). Figure 3 shows the increase in soil C flux detected after 1900 and the significant increases in the last half of the 2oth century (Friedlingstein et al. 2014).

Figure 3. Soil organic carbon sensitivity to environmental change (Friedlingstein et al. 2014).

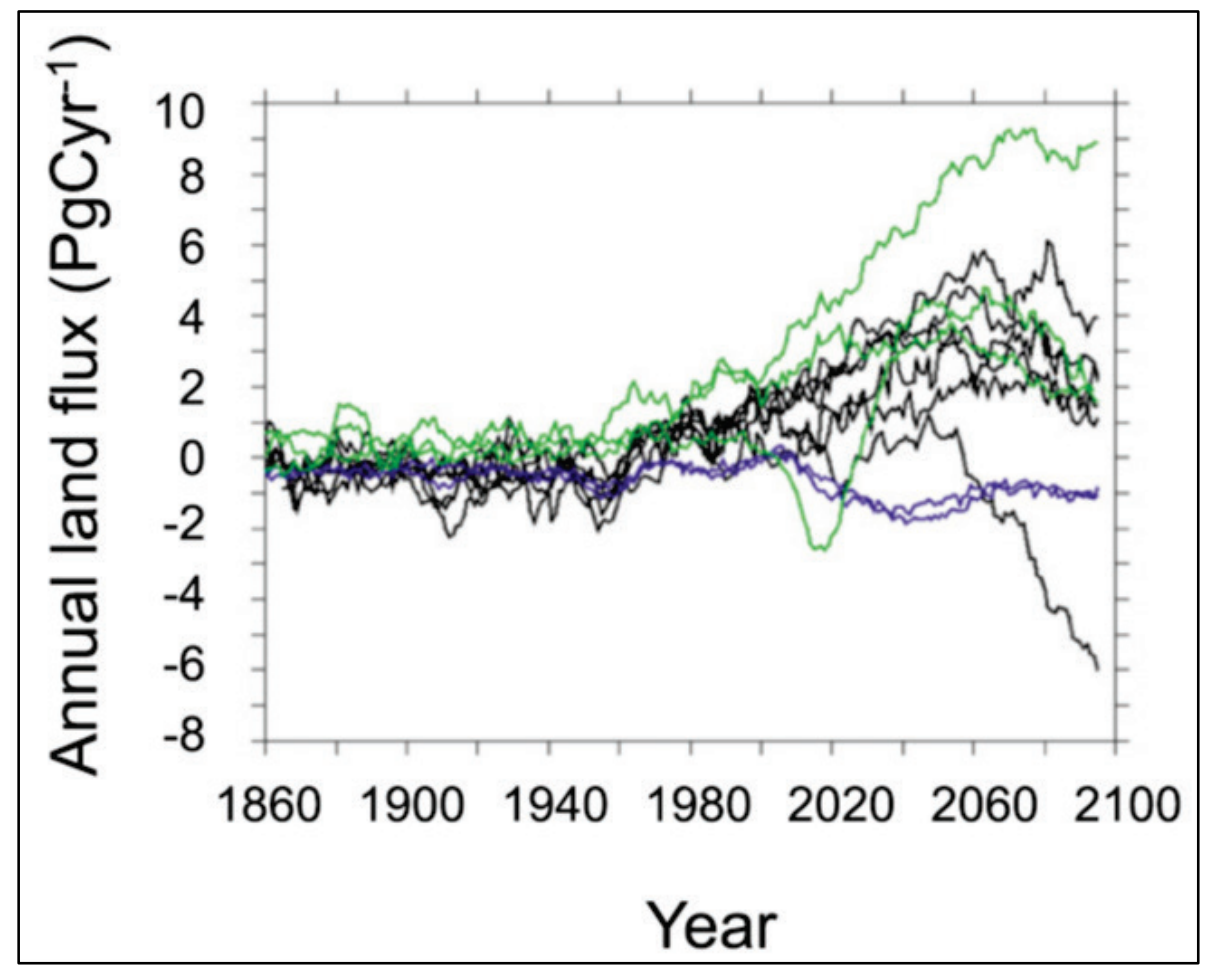


In Figure 3, the colored lines represent the summary of 11 specific climate models; blue/purple lines are for earth system models (ESMs) accounting for a terrestrial nitrogen cycle, green lines are for ESMs describing emissions of $\mathrm{CO}_{2}$ due to land use change calculated as anthropogenic influence.

The carbon content of soils may increase or decrease with climate and land use change. The major issue is to assess whether these changes are detectable through soil monitoring efforts, taking into account the uncertainties caused by spatial heterogeneity, sampling methods, analytical errors and study scale (Lal 2010). The evaluation of the confidence with which changes in carbon content can be detected is important for implementing any soil or carbon monitoring program.

Soil properties, including temperature, moisture, texture, and SOC, vary vertically from surface to bedrock along the soil horizons. The SOC turnover rate decreases with depth; knowledge of the depth distribution of $\mathrm{SOC}$, and its proper representation in models, is critical for predicting the response of subsoil carbon to environmental change and potential climate feedbacks (Trumbore 2009; Marin-Spiotta et al. 2011).

There are several mechanisms by which SOC can move through the soil profile, such as:

- Plant roots and root exudates (Jackson et al. 1996; Rasse et al. 2006). While root carbon flux is still poorly understood, what is known is that grasses have the shallowest root profiles, trees are intermediate and shrubs have the deepest root profiles. Also, the mean residence time of root-derived SOC is 2.4 times higher than that of shoot derived SOC (Rasse et al. 2005). The factors that affect root carbon flux remain to be elucidated.

- Bioturbation (Cernansky 2016; Kristensen et al. 2012). Earthworms, nematodes, termites and ants, for example, are responsible for incorporating large masses of surface organic matter, and nutrients, into the deeper layers of the soil. Soil fauna increase litter decomposition rates significantly in many regions of the country (Wall et al. 2008). Changes in climate have been reported to alter the nematode populations, which resulted in changes in litter decomposition rates. A follow-up study by Garcia-Palacios et al. (2013) and the Garcia-Palacios et al. corrigendum (2013), estimated that 
excluding soil fauna would reduce the decomposition rate by a global average of approximately $37 \%$. Thus, a small change in atmospheric carbon could result in larger changes in soil carbon flux. The nuances in this feedback loop are one area that requires further research to fully understand its significance.

- Vertical transport of SOC through the following:

- Cryoturbation, the mixing of different soil horizons due to freezing and thawing (Ping et al. 2015; Bockheim 2007)

- Podzolization, the process by which the upper layers of soil become acidic through leaching of bases which are deposited in the lower soil horizons (White 2006; Lundstrom et al. 2000)

- Preferential flowpaths such as tunnels left by dead roots and abandoned ant and termite colonies (Chabbi et al. 2009; Bundt et al. 2001).

- Human factors such as ploughing and ponding soils for cultivation.

This spatial variability of SOC content strongly influences the ability to detect changes, particularly at field-scale (Conant and Paustian 2002; Conant et al. 2003). Numerous field-scale studies have addressed this issue (for example, Conant and Paustian 2002; Garten and Wullscheleger 1999; Conant et al. 2003; Conen et al. 2003; Saby and Arrouays 2004; Smith 2004). Mishra et al. (2009) reported the depth distribution of SOC stocks in the state of Indiana including both agricultural and urban areas (Figure 4).

Estimates of soil carbon can also be made using vegetation classifications, vegetation biomass, vegetative growth, and soil carbon data. Vegetation can be classified using the National Land Cover Database (NLCD), a dataset from 2001 to 2011 at a $30 \mathrm{~m}$ resolution (Homer et al. 2015). The NLCD divides vegetation into very generalized categories: three forest types (deciduous, evergreen, mixed), shrubs/scrub, grasslands, woody wetlands, herbaceous wetlands, pasture, and cropland. Vegetation biomass is estimated using the National Biomass and Carbon Dataset (NBCD), that provides a $30 \mathrm{~m}$ resolution of estimated canopy height, standing biomass, and vegetation above-ground carbon stock estimates (Kellndorfer et al. 2012). Vegetative growth is estimated using Moderate Resolution Imaging Spectroradiometer (MODIS) and Normalized Difference Vegetation Index (NDVI) data. Both MODIS and NDVI 
estimate vegetation based on absorbed photosynthetically active radiation (PAR). From this data, plant biomass and net primary productivity can be estimated to obtain relative growth rates and amounts of vegetation change over time. Both MODIS and NDVI provide monthly measurements; NDVI is at $1 \mathrm{~km}$ resolution and MODIS is at $500 \mathrm{~m}$ resolution. Soil carbon is estimated from the Soil Survey Geographic Database (SSURGO).

Figure 4. Estimating depth distribution of SOC stocks in Indiana when comparing top soil and sub soil concentrations.

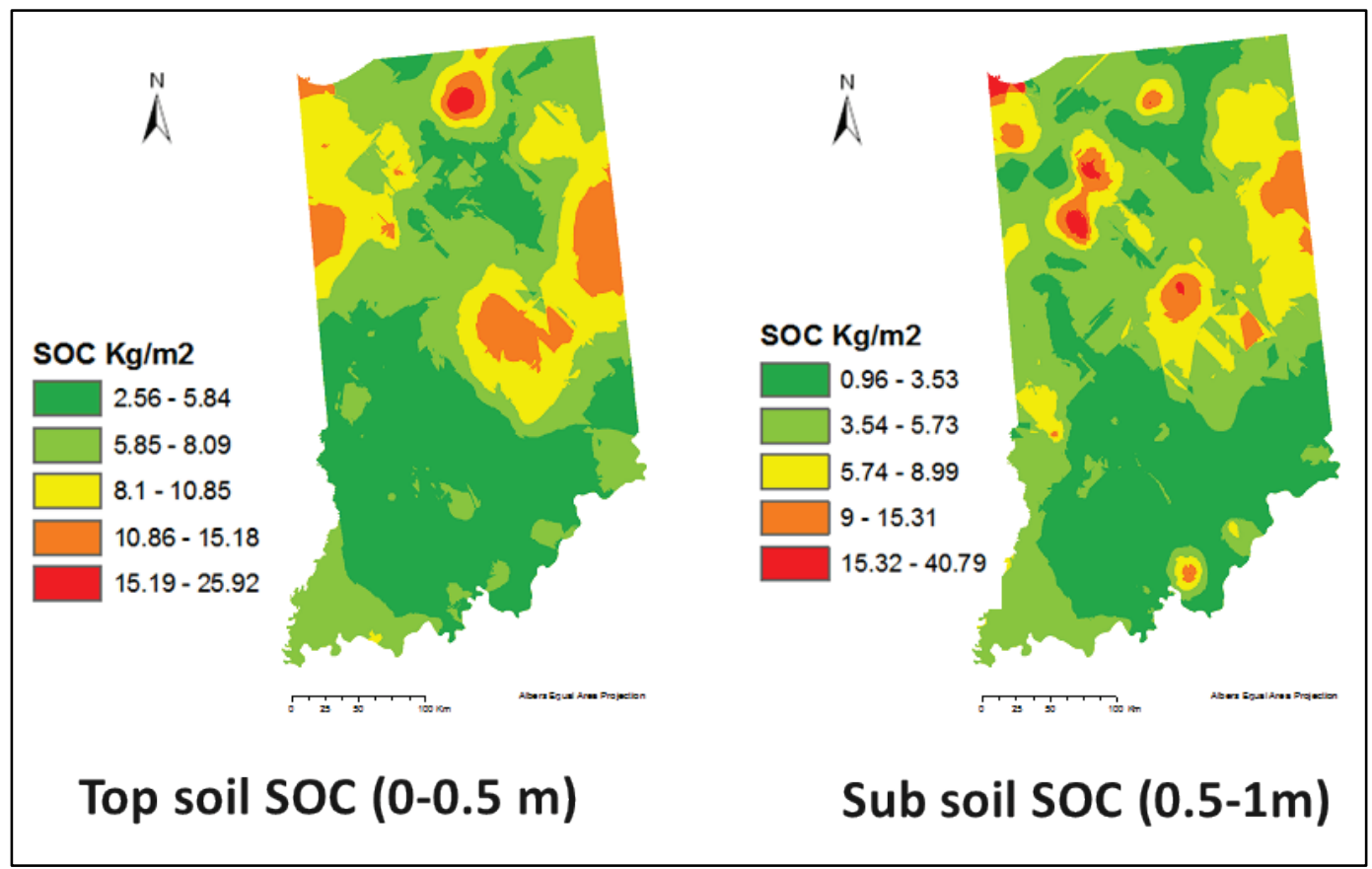

\subsection{Monitoring soil carbon}

In this context, soil monitoring can be defined as taking repeated observations, measurement and evaluation of soils at a particular site along with related environmental or technical data, according to prearranged schedules in space and time, using standardized methods for data collection and analysis (such as provided by Donovan (2013)). Spatial distribution of collected soil samples should be representative of soil type, land use and climate conditions and the spatial arrangement of samples may be random or on a regular grid (Jones and Verheijen 2008).

\subsection{Verifying soil carbon models}

Considering a single, hypothetical, study site, results from power analysis has shown that soils with low coefficients of variation $(<25 \%)$ in SOC 
require $>100$ samples to detect changes of $3 \% \mathrm{C}$ from the background (Garten and Wullschleger 1999). For soils with a large coefficient of variation, prohibitively large numbers of samples are required (Conen et al. 2004). In this case, the study site could be revisited on a second and subsequent occasions, as this is the most efficient way of monitoring SOC change (Lark et al. 2006). For any particular monitoring study of a variable $x, n$ sites are sampled at time to and again at time $t_{1}$. An estimate of the average change $(\overline{\mathrm{A}})$ in $x$ is calculated as;

$$
\overline{\mathrm{A}}=\sum_{i=1}^{n}\left(S O C_{i, t_{0}}-S O C_{i, t_{1}}\right) / n
$$

Where, $S O C_{i, t}$ is the SOC measurement at site $i$ at time $t$ and $n$ is the number of sites in the monitoring study. An estimate of the standard error of $\overline{\mathrm{A}}$ is $\sqrt{\frac{s_{A}^{2}}{n}}$ where $S_{A}^{2}$ is an estimate of the variance of the differences in SOC (de Gruijter et al. 2006).

Several insights can be reported after considering the results of several carbon mapping studies conducted from 2009 to 2014.

- A variety of mathematical functions (spline functions) are presently being used to describe the depth distribution of SOC.

- The most accurate results have been obtained when individual functions are fitted in each soil profile and used in a machine learning approach, as no single function can fit all profiles.

- These mapping studies have consistently found that prediction accuracy decreases with soil depth.

- It has been difficult to find appropriate environmental predictors of model (spline) coefficients for sub-soil carbon stocks.

- Validation $\mathrm{R}^{2}$ values are substantially lower in comparison to calibration $\mathrm{R}^{2}$ values, meaning carbon over-estimation by the current models.

There are data gaps in the land models that attempt to predict the depth distribution of SOC stocks. For example:

- Despite discretizing soils vertically for soil moisture and energy calculations, most coupled carbon-climate models typically represent SOC biogeochemistry with a single-layer (Todd-Brown et al. 2013; el Masri et al. 2015). 
- Jenkinson and Coleman (2008) developed and added two parameters in RothC-26.3 to describe the subsoil biogeochemistry. One parameter moves organic carbon down the soil profile and a second parameter slows decomposition of organic matter at depth.

- Koven et al. (2013) implemented soil carbon and nitrogen vertical biogeochemistry in a community land model. Most models do not consider nitrogen along with the carbon stocks.

- In general, the land models (Century, RothC, TEM and CLM4.5) assume an exponential decrease of carbon with depth. This assumption has been proven wrong in several instances. Century and RothC represent SOC down to $1 \mathrm{~m}$ in depth. CLM4.5 represents SOC biogeochemistry up to $3.8 \mathrm{~m}$ in depth. However, tropical soils contain substantial SOC several meters deep.

U Mishra ${ }^{1}$ is attempting to represent vertical biogeochemistry of SOC stocks in the Integrated Science Assessment model. The study explored a variety of methods to represent the vertical heterogeneity of SOC including soil type, land cover type, and ecoregion. Also, the study has reported that ecoregion-based stratification of the soil profile data provided the best fit to the observed data. The model now needs better representation of organic layer SOC and the impact of soil wetness.

\subsection{Research needs}

In summary, estimates of SOC stocks and their representation in models have started to include parameters for vertical heterogeneity. Representing belowground biogeochemistry will make the most sense in terms of soil horizons (layers at depth). A knowledge gap remains concerning the carbon fluxes in different soil horizons in response to perturbations from cold, biological influence, and human intervention. A current share of uncertainty in model predictions due to soil carbon could be decreased by proper representation of both vertical and lateral heterogeneity. Accounting for both spatial and vertical heterogeneity of $\mathrm{SOC}$ is a prerequisite for proper estimates of SOC sequestration or release.

Also, classification of vegetation at only five levels of natural terrestrial vegetation in NLCD removes plant community level estimates, which have significant influences on soil carbon. Plant biomass is estimated from a single data point. Estimating plant activity using NDVI and MODIS is

1 U. Mishra, Argonne National Laboratory, Lemont, IL pers. comm., July 2016. 
troublesome, as algorithms to convert absorbance of PAR into plant growth and production have high uncertainties. Soil carbon data often comes from soil survey maps and soil sample analyses that were conducted for soil types nationwide. Survey maps have inconsistent boundary accuracy and chemical attributes, often have little coverage or replication, and often, only include soil surface horizons.

One option to improve carbon estimates is to directly measure them. Eddy covariance systems are currently in use across the United States to measure carbon flux. These systems are expensive to maintain and are primarily funded by the National Science Foundation (NSF) through the National Ecological Observatory Network (NEON). This network of ecological research stations collects significant environmental data. Partnering by DoD with this network could allow direct measurements of carbon flux on DoD lands, allowing a direct comparison between military training environments and ecosystem preserves for numerous environmental variables. Additionally, many NEON sites are located in close proximity to, and on similar ecosystems representing major DoD installations; this data would allow for direct comparisons (Figure 5). Many of these paired locations represent the major ecosystems of the United States (Table 1).

Figure 5. NEON sites and major DoD installations across the United States. Many DoD installations are in close proximity to NEON sites and occur on comparable ecosystems.

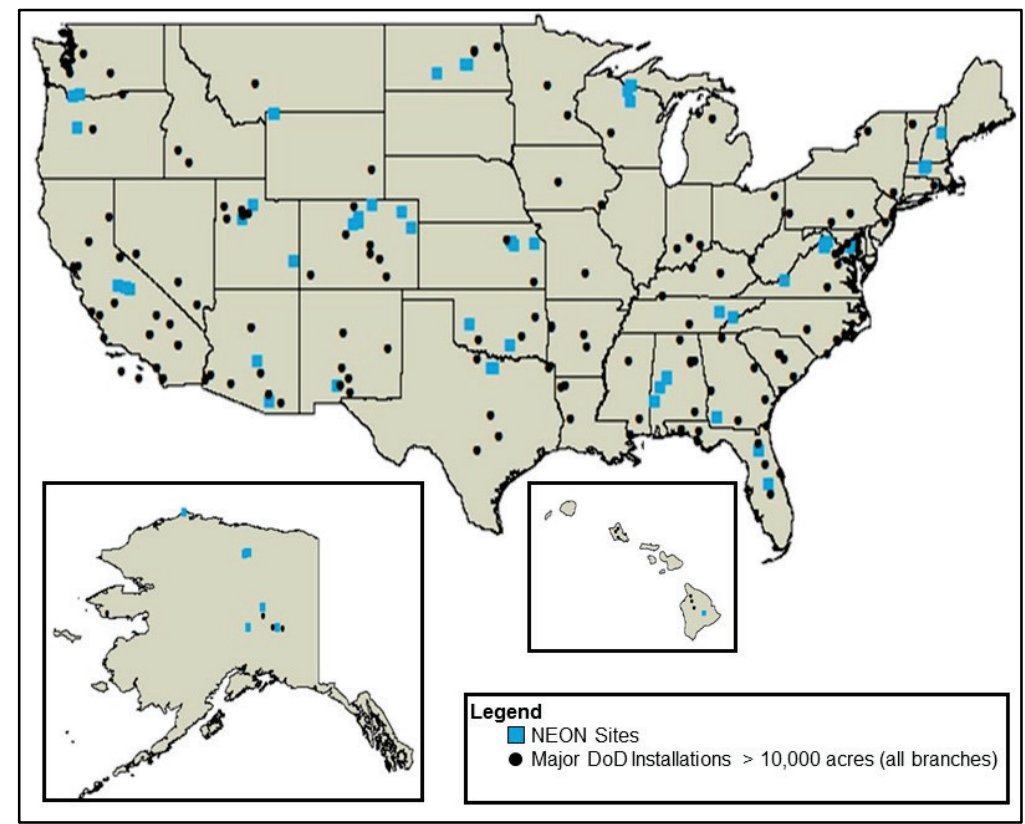


Table 1. Paired NEON sites and DoD installations in close proximity with comparable ecosystems.

\begin{tabular}{|l|l|l|l|}
\hline NEON Site & DOD Installation & Distance (miles) & Ecosystem \\
\hline Delta Junction & Fort Greely & 0 & Taiga \\
\hline Konza Prairie & Fort Riley & 22 & Prairie \\
\hline Santa Rita & Fort Huachuca & 52 & Desert \\
\hline Jornada & Fort Bliss & 52 & Desert Grassland/ Shrubland \\
\hline Unaqui-Ault & Dugway Proving Ground & 62 & Shrubland \\
\hline LBJ National Grassland & Fort Sill & 120 & Grassland \\
\hline Jones Ecological Research Center & Fort Benning & 109 & Longleaf Forest \\
\hline Jones Ecological Research Center & Eglin Air force Base & 162 & Longleaf Forest \\
\hline Oak Ridge National Lab & Fort Campbell & 221 & Oak-Hickory Forest \\
\hline Oak Ridge National Lab & Fort Knox & 227 & Oak-Hickory Forest \\
\hline
\end{tabular}




\section{Plant Processes Controlling Carbon Flux}

\subsection{Plant variation}

Variation in vegetation occurring in ecosystems has a profound influence on soil carbon dynamics. This variation is a product of environment and interactions between plant species. While forests produce the greatest carbon stocks, open environments (such as, steppe, tundra, desert) produce the greatest relative amounts of soil carbon stocks (Table 2). This is due to a greater root:shoot ratio in these environments, where competition for soil resources is greater than for sunlight.

Table 2. Estimates of carbon stocks in ecosystems (Adams 2016).

\begin{tabular}{|l|c|c|c|c|}
\hline Ecosystem type & $\begin{array}{c}\text { Vegetation } \\
\left(\mathrm{kg} \mathrm{C}^{-2}\right)\end{array}$ & $\begin{array}{c}\text { Soils } \\
\left(\mathrm{kg} \mathrm{C}^{-2}\right)\end{array}$ & $\begin{array}{c}\text { Litter/Debris } \\
\left(\mathrm{kg} \mathrm{C}^{-2}\right)\end{array}$ & $\begin{array}{c}\text { Total } \\
\left(\mathrm{kg} \mathrm{C}^{-2}\right)\end{array}$ \\
\hline Giant Conifer Forest & 35 & 26 & 12 & 73 \\
\hline Warm Temperate Forest & 19 & 15 & 4 & 37 \\
\hline Cool Temperate Forest & 16 & 14 & 3 & 33 \\
\hline Main Taiga & 8 & 22 & 2 & 32 \\
\hline Southern Taiga & 14 & 14 & 2 & 29 \\
\hline Tropical Montane Forest & 13 & 13 & 2 & 28 \\
\hline Moist Steppe & 1 & 25 & 0 & 26 \\
\hline Forest Steppe & 1 & 22 & 1 & 24 \\
\hline Lowland Tundra & 1 & 21 & 0 & 22 \\
\hline Temperate Woodland & 10 & 10 & 2 & 21 \\
\hline Forest-Tundra & 1 & 17 & 2 & 20 \\
\hline Open Boreal Woodland & 5 & 13 & 2 & 19 \\
\hline Mediterranean Forest & 10 & 8 & 1 & 19 \\
\hline Mediterranean Scrub & 4 & 6 & 1 & 11 \\
\hline Temperate Scrub & 5 & 5 & 1 & 10 \\
\hline Dry Steppe & 1 & 8 & 0 & 8 \\
\hline Temperate Semi-Desert & .5 & 6 & 0 & 6 \\
\hline Steppe-tundra & .5 & 6 & 0 & 6 \\
\hline Montane/Dry Tundra & .5 & 5 & 0 & .1 \\
\hline Polar/Montane Desert & .1 & 0 & 0 & \\
\hline Temperate Desert & .1 & 0 & 0 & 2 \\
\hline
\end{tabular}


Root depth is important for soil carbon retention; deeper roots contribute greater proportions to long term soil carbon pools. Soils in the top $0.2 \mathrm{~m}$ contain $615 \mathrm{Gt}$ of carbon with a mean residence time of a few hundred years, while soils in the top $3 \mathrm{~m}$ contain 2,344 Gt of carbon (more than all the carbon in the atmosphere) with a mean residence time of 2-10 millennia (Fontaine et al. 2007). This increase in residence time with soil depth is a result of slower decomposition due to fewer nutritional resources to support decomposition at increasing depth (Spohn et al. 2016). Rooting depth is primarily a function of plant type, but can also be influenced by climate and soil type, where total SOC increases with precipitation (surface soils) and clay content (deep soils) (Jobbagy and Jackson 2000), but appear to be more dependent on soil type than climate (Mathieu et al. 2015). Root:shoot ratios, rooting depth, root biomass, and root depth distribution all vary by ecosystem (Table 3). Generally, trees have the highest maximum rooting depths, followed by shrubs and finally herbaceous vegetation. Forbs are highly variable, but certain species can produce very deep roots. Also, perennials tend to have deeper roots than annual plants. The $\mathrm{C} 4$ grasses (they produce a four-carbon sugar, oxaloacetate, during the Calvin cycle of photosynthesis) also have deeper roots than $\mathrm{C}_{3}$ grasses (which produce two, three-carbon sugars during the Calvin cycle). The $\mathrm{C} 4$ plants are more energy intensive and bring more $\mathrm{CO}_{2}$ into the process. Examples of $\mathrm{C}_{4}$ plants include corn or maize, sugarcane, sorghum and different millets, as well as switchgrass. C3 plants include beans, rice, wheat, and woody trees.

Table 3. Root properties of ecosystems (Canadell et al. 1996; Jackson et al. 1996).

\begin{tabular}{|l|c|c|c|c|}
\hline Biome & $\begin{array}{c}\text { Root: } \\
\text { Shoot }\end{array}$ & $\begin{array}{c}\text { Maximum } \\
\text { Rooting Depth } \\
(\mathrm{m})\end{array}$ & $\begin{array}{c}\text { Root Biomass } \\
\left(\mathbf{k g ~ m}^{-2}\right)\end{array}$ & $\begin{array}{c}\text { \% in Top } \\
\mathbf{3 0 ~} \mathbf{~ c m}\end{array}$ \\
\hline Tropical Grassland/Savanna & 0.7 & 15 & 1.4 & 57 \\
\hline Desert & 4.5 & 9.5 & 1.2 & 53 \\
\hline Tropical Evergreen Forest & 0.19 & 7.3 & 4.9 & 69 \\
\hline Sclerophyllous Shrubland & 1.2 & 5.2 & 4.8 & 67 \\
\hline Temperate Coniferous Forest & 0.18 & 3.9 & 4.4 & 52 \\
\hline Tropical Deciduous Forest & 0.34 & 3.7 & 4.1 & 70 \\
\hline Temperate Deciduous Forest & 0.23 & 2.9 & 4.2 & 65 \\
\hline Temperate Grassland & 3.7 & 2.6 & 1.4 & 83 \\
\hline Cropland & 0.1 & 2.1 & 0.15 & 70 \\
\hline Boreal Forest & 0.32 & 2 & 2.9 & 83 \\
\hline Tundra & 6.6 & 0.5 & 1.2 & 93 \\
\hline
\end{tabular}




\subsection{Rhizosphere processes}

\subsubsection{Plants}

Up to 60\% (higher for perennials than annuals) of the carbon fixed by plants through photosynthesis ends up in the soil, comprising 30-40\% of the total SOC input while occupying only $2-3 \%$ of soil volume (Grayston et al. 1996; Jones et al. 2004). As plants grow, roots are constantly dying and being replaced. This root turnover is a primary source of soil organic matter, as the dead roots are decomposed by soil microbes. Root turnover is highly variable and dependent on a number of factors, including root size, environmental conditions, and plant type (Table 4).

Table 4. Estimates of root turnover by ecosystem (Lauenroth and Gill 2003).

\begin{tabular}{|l|l|}
\hline Ecosystem & $\begin{array}{l}\text { Root Turnover } \\
\text { (Years) }\end{array}$ \\
\hline Temperate Conifer Forest & $0.08-2.57$ \\
\hline Temperate Deciduous Forest & $0.18-1.42$ \\
\hline Boreal Forest & $0.26-0.34$ \\
\hline Temperate Grassland & 0.47 \\
\hline Temperate Shrubland & 0.44 \\
\hline
\end{tabular}

As noted in Chapter 2 of this report, roots in the rhizosphere are also a significant source of bioturbation and carbon turnover. Tunnels left by dead roots contribute to higher moisture levels in the deeper soil horizons that are conducive to organic matter decomposition.

\subsubsection{Bacteria}

Rhizosphere microorganisms associated with roots and, roots in the boreal forest, specifically, have been shown in models to store up to $70 \%$ of the stored carbon in a chronosequence, a set of forested sites that share similar attributes but are of different ages (Clemmensen et al. 2013). Up to 10\% of the total carbon fixed by plants through photosynthesis can be exuded by plant roots (Jones et al. 2004). These exudates are comprised of sugars and other polysaccharides; amino, fatty and organic acids; enzymes; sterols; vitamins; nucleotides; and numerous other secondary metabolites and miscellaneous molecules (Uren 2001). One of these exudates is a gel-like substance excreted into the soil surrounding the roots and known as an extracellular polysaccharides (EPS), or simply, a biopolymer. The natural functions of the EPS in the rhizosphere include surface adhesion between 
soil particles, self-adhesion of cells into biofilms, formation of protective barriers, water retention around roots, and nutrient accumulation (Laspidou and Rittmann 2002), as well as pathogen resistance, stress response and protection, communication with soil microbes, and reduction of competing neighbors (Uren 2001). Addition of concentrated biopolymer to the soil results in increased seed germination success, increased above and below-ground biomass and reduced soil loss through erosion (Larson et al. 2016). These attributes tend to conserve soil carbon.

\subsubsection{Fungi}

Most plant species associate with beneficial root fungi, called mycorrhizal fungi. These fungi form secondary root structures that can access and chemically alter soil resources to increase nutrient availability to plants. Ectomycorrhizal fungi (EMF) associate primarily with conifers, although they form associations with many deciduous trees and other plants. Arbuscular mycorrhizal fungi (AMF) associate primarily with grasses and forbs, but also form associations with many trees and shrubs. EMF consist of thousands of fungal species that associate with a narrower range of hosts (around 2\% of all plant species), while AMF consist of hundreds of fungal species that associate with a very wide range of hosts (around 80\% of all plant families). EMF can function as free-living saprophytic fungi in the absence of plant hosts, while AMF cannot survive without a plant host association. EMF form sheaths around fine root tips and do not penetrate root cells, while AMF form vast hyphal networks within plant roots that penetrate root cells. Although there are immense differences between the two mycorrhizal types, they both exert substantial influences on soil carbon cycling.

AMF can produce over $100 \mathrm{~m}$ of hyphae per $\mathrm{g}$ of soil (Miller et al. 1995), can grow at a rate of more than a $\mathrm{m}$ per day per $\mathrm{g}$ soil, and have a lifespan of less than a week (Staddon et al. 2003). Further, these hyphae produce a substance, called glomalin, that binds soil particles together to increase soil aggregation, and alone can comprise more than a quarter of the SOC pool (Nichols 2003). Thus, AMF have a major role in SOC storage.

However, not all AMF are created equal. The order Glomerales represents the largest group of AMF, which generally provide the greatest benefits to their plant hosts but produces less soil hyphae and glomalin. The family Gigasporaceae, on the other hand, produces extensive soil hyphae that 
produce greater amounts of glomalin and appear to be better adapted to soils low in nitrogen.

EMF hyphal production averages around $160 \mathrm{~kg} \mathrm{ha}^{-1}$ per growing season in the top $10 \mathrm{~cm}$ of soil across a range of forest types, with the highest production occurring in warm temperate forests such as exist in the southeastern United States (Ekblad et al. 2013). In a longleaf pine forest, EMF biomass was $300 \mathrm{~kg} \mathrm{ha}^{-1}$ with a production of $2800 \mathrm{~kg} \mathrm{ha}^{-1}$ and turnover around a month (Hendricks et al. 2016).

Across ecosystems in North America, forests are generally dominated by EMF-associated trees (Table 5) with understories dominated by AMFassociated plants. In grasslands and shrublands, AMF occur almost exclusively. Woodlands are co-dominated by EMF and AMF. EMF appear to be more effective at increasing carbon storage in soils through their ability to produce and release enzymes to degrade organic matter (Averill et al. 2014). This degradation increases nitrogen availability, which is then taken up by the EMF for plant utilization. Alternatively, AMF appear to acquire nitrogen through priming of soil bacteria, which increases mineralization of SOC (Brzostek et al. 2015; Paterson et al. 2016). However, the exact mechanisms and net impacts of these activities are not fully understood.

Table 5. Mycorrhizal status of common North American trees.

\begin{tabular}{|l|l|l|}
\hline Genus & Common Name & Mycorrhizal Status \\
\hline Acer & Maple & AMF \\
\hline Celtis & Hackberry & AMF \\
\hline Fraxinus & Ash & AMF \\
\hline Juglans & Walnut & AMF \\
\hline Juniperus & Juniper & AMF \\
\hline Liquidambar & Sweetgum & AMF \\
\hline Liriodendron & Tuliptree & AMF \\
\hline Platanus & Sycamore & AMF \\
\hline Betula & Birch & EMF \\
\hline Fagus & Beech & EMF \\
\hline Carya & Hickory & EMF \\
\hline Picea & Spruce & EMF \\
\hline Pinus & Pine & EMF \\
\hline Quercus & Oak & EMF \\
\hline & &
\end{tabular}




\begin{tabular}{|l|l|l|}
\hline Genus & Common Name & Mycorrhizal Status \\
\hline Tilia & Basswood & EMF \\
\hline Alnus & Alder & Both \\
\hline Crataegus & Hawthorn & Both \\
\hline Populus & Cottonwood/Poplar & Both \\
\hline Prunus & Cherry & Both \\
\hline Pseudotsuga & Fir & Both \\
\hline Salix & Willow & Both \\
\hline Tsuga & Hemlock & Both \\
\hline Ulmus & Elm & Both \\
\hline
\end{tabular}




\section{Land Management Effects on Soil Carbon Flux: Strategies to Maximize Carbon Sequestration in Soil}

There are several major carbon soil sinks available on DoD installations and facilities, as shown in Figure 6. Many facets of land management efforts on military lands already promote soil carbon storage. Maintenance of desirable perennial native plant communities for soil stabilization, habitat quality and training realism tend to increase soil carbon. Management practices directed towards improving annual vegetation production, whether through forest growth or agricultural practices, also generally increase residue carbon input into the soil (Table 6). This results in greater soil aggregate stability and greater aggregate associated SOC levels. The soil has an increased capability of long-term carbon stabilization (Kong et al. 2005). However, more adjustments could be made to current practices that increase soil carbon storage without negatively impacting other requirements. These land management changes could significantly increase carbon soil sequestration.

Figure 6. Land sinks for atmospheric carbon available on many DoD installations on facilities.

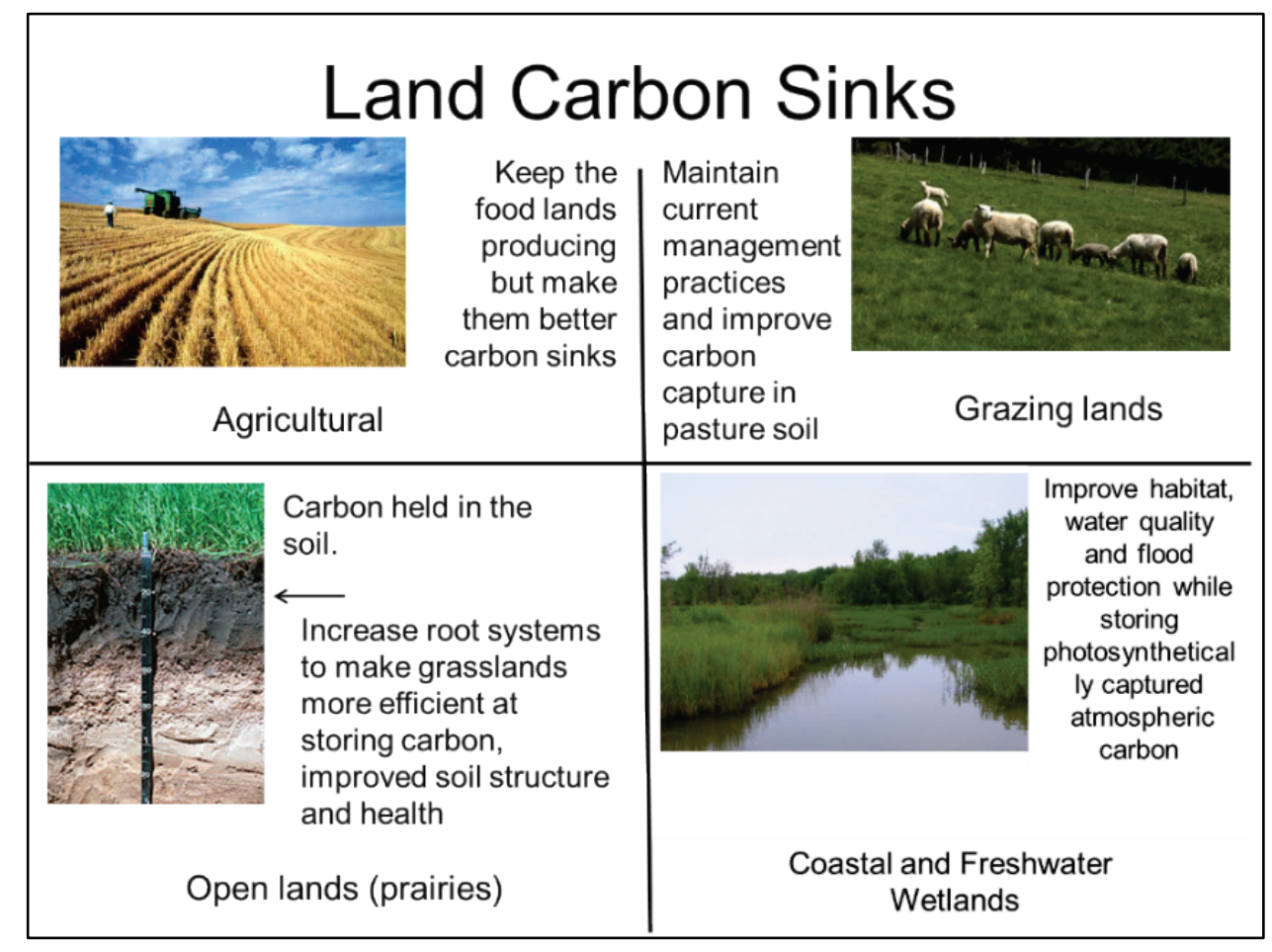


Table 6. Summary of inputs into soil that either increase/decrease soil carbon.

\begin{tabular}{|l|l|}
\hline Carbon Inputs & Effect on Soil Carbon (Gain/Loss) \\
\hline Increase in root mass & $\begin{array}{l}\text { Decreased soil erosion (carbon gain) } \\
\text { Increase rhizosphere activity (carbon gain/ carbon } \\
\text { loss) }\end{array}$ \\
\hline Decrease in root mass & $\begin{array}{l}\text { Increased soil erosion (carbon loss) or re-deposition of } \\
\text { C at depth (carbon gain) }\end{array}$ \\
\hline Increase in soil microbial communities & Increase soil respiration (carbon loss) \\
\hline Increase in microbial exudates & $\begin{array}{l}\text { Increase in soluble soil carbon leaching to groundwater } \\
\text { (carbon loss, but not to the atmosphere) }\end{array}$ \\
\hline Increase in ectomycorrhizal fungi (EMF) & $\begin{array}{l}\text { Increased generation of soil humic material (carbon } \\
\text { gain) }\end{array}$ \\
\hline \multirow{2}{*}{$\begin{array}{l}\text { Increase in bioturbation and soil carbon spatial } \\
\text { distribution by soil fauna (nematodes, ants, } \\
\text { earthworms, etc) }\end{array}$} & $\begin{array}{l}\text { Increase in decomposition of soil surface litter (carbon } \\
\text { gain) }\end{array}$ \\
\cline { 2 - 2 } & $\begin{array}{l}\text { Carbon from decomposition respired by bacteria } \\
\text { (carbon loss) or converted to soil humics (carbon gain) }\end{array}$ \\
\hline \multirow{2}{*}{ Use of soil amendments (biochars, biopolymers) } & $\begin{array}{l}\text { Increase carbon input into soil (carbon gain), decrease } \\
\text { erosion (carbon gain) }\end{array}$ \\
\hline
\end{tabular}

However, some carbon inputs could result in either a gain or a loss of soil carbon. The factors that determine gain/loss are not always well understood and provide much uncertainty in modeling efforts.

\subsection{Forestry}

The RaCA by the NRCS found that forests are the LULC class showing the highest mean SOC stocks (West et al. 2013). Old growth forests continue

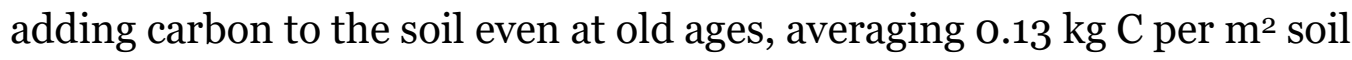
per year (Luyssaert et al. 2008). Further, shoot carbon in forests is estimated to increase $1-2 \%$ over the previous year growth (Alexandrov 2007). Timber harvesting can cause soils to become net sources of carbon for decades. While forest management is often economically driven, adjusting harvesting schedules to maximize carbon production and minimize losses could dramatically reduce soil carbon mineralization and increase sequestration of atmospheric carbon. Managing forests to maximize ecosystem services, such as carbon storage, could be achieved just by comparing common practices to determine their impacts on important, yet overlooked, ecosystem characteristics.

Ongoing research on military lands is comparing forestry management methods to identify their impacts on mycorrhizal fungi that play a vital 
role in soil carbon storage ${ }^{1}$. Preliminary data (Anna 2009)(R. Busby ${ }^{1}$ pers. comm., July 2016) suggests that fires have a much greater impact on AMF than EMF, and herbicide utilization to control unwanted woody vegetation facilitates increases in AMF density. Removal of understorey vegetation has shown mixed effects on mycorrhizal fungi. Some forests show no effect of removal on SOC content, while others show significant losses ${ }^{1}$. Additional research is needed to understand how specific management activities affect SOC accumulation and other ecosystem services.

\subsection{Grazing/Agriculture}

Perennial plants produce greater root biomass and increase SOC compared to annual plants. Also, perennial crop plants negate the need for annual soil tillage that releases tremendous volumes of soil carbon. Soil carbon storage on agricultural outlease lands could be increased by:

- Converting these lands to perennial cropping systems,

- Shifting to biomass fuels production to reduce GHG emissions from energy production, and by

- Adding additional carbon to soil through waste paper mulch or biopolymer soil amendment once every few years (frequency not yet established).

Grazing also impacts SOC storage through grazing intensity, rotation timelines, and type of vegetation. However, since grazing lands are already in a perennial cropping system, there are fewer management options for change and the potential to increase SOC storage is lower.

\subsection{Prescribed Burning and Wildfire}

Fires have variable impacts on soil carbon. Some fires increase soil carbon while some decrease it. This appears to be site specific and dependent on a number of factors such as timing, intensity and frequency (Hurteau and Brooks 2011). Fires in native North American grasslands increase primary production and maintain the dominance of desirable perennial vegetation, leading to overall increases in soil carbon stocks. Forest wildfires however, often leave soil bare and vulnerable to erosion and the concomitant carbon loss (Delwiche 2009). Erosion control soil amendments along with desired perrenial grass seeds may be a method of reducing soil loss through

${ }^{1}$ R. Busby, USACE ERDC CERL, Champaign, IL pers. comm., July 2016. 
erosion after wildfires (Larson et al. 2016). Because fires are common and sometimes necessary on military lands (either controlled or accidental), additional data regarding how to incorporate soil carbon management into fire management plans could improve carbon sequestration while maintaining the desired environmental properties provided by fires.

\subsection{Invasive plant species}

Invasion of non-native plant species can alter SOC in multiple ways. First, many are annuals or short-lived perennials that displace longer lived native perennial plants that devote more carbon to root production. Second, plant invasions reduce biodiversity, which decreases SOC. Finally, non-native plant species generally don't associate as heavily with mycorrhizal fungi (Busby et al. 2011). This disassociation, known as invasional meltdown, degrades mycorrhizal fungi in soils that are important for soil carbon storage, healthy soils, and native plant communities. In areas where invasive annual plants replace native perennial plants, such as the cheatgrass invasion in the Intermountain West, soil carbon losses are considerable (Koteen et al. 2011).

\subsection{Biodiversity}

Maintenance of diverse plant communities on military lands is promoted for a number of reasons, including habitat, resilience, and training realism. An additional benefit is increased SOC (Fornara and Tilman 2008). However, not all plant functional groups are associated with high SOC. Replacement of $\mathrm{C}_{4}$ grasses in prairies with $\mathrm{C}_{3}$ grasses reduces overall SOC (Fornara and Tilman 2012). Soils under evergreen trees have higher SOC than deciduous trees (Setala et al. 2016). Species within functional groups also vary in their ability to accumulate and store SOC (Ahmed et al. 2016). Thus, an increased understanding of which plant species and groups store more SOC in different environments could be used in land management to increase soil carbon storage.

\subsection{Soil amendments}

\subsubsection{Biochar}

Biochar is the byproduct of gasification and pyrolysis sytems. This byproduct can be useful as both a soil amendment to improve soil health and for increasing SOC. Biochar has the potential to increase soil carbon through the following: 
- Direct addition of carbon to the soil

- Increasing the density and diversity of rhizosphere bacteria and fungi

- Decreasing in soil carbon loss through erosion.

However, different sources of material and different production processes affect the biochar properties and how they interact with different soil types (Ahmedna et al. 2000; Fang et al. 2014; Sigua et al. 2014). Additional research is necessary to determine optimal process parameters for what type of biochar is desirable, where, when, and how much to apply to soils, including logistics for production, and application at an operational scale.

\subsubsection{Paper waste}

Paper waste at DoD installations is frequently pulverized to a particle size that renders it unfit for recycling. The military produces large amounts of this waste material, which is often incinerated or landfilled. Current research is evaluating this waste product as a soil amendment to increase soil carbon in training lands. Adding waste materials such as paper, with a high carbon:nitrogen ratio, ties up soil nitrogen and promotes establishment of perennial vegetation that increase soil carbon through increased root growth.

Paper waste has the potential to increase soil carbon through the following:

- Decrease of soil carbon loss through erosion

- Increasing the biomass available for decomposition by soil fauna and microbes

- Increasing below ground biomass.

\subsubsection{Fertilizer}

Adding fertilizer to training areas occurs routinely when rehabilitation with seeding occurs. Fertilizing healthy stands of vegetation has the capacity to increase soil carbon, but can also lead to degraded ecosystems due to reductions in plant biodiversity and promotion of undesirable vegetation. Thus, understanding where this amendment can yield positive effects and where it is unwarranted is needed for effective utilization. 
Proper fertilization increases soil carbon through the following:

- Increase in above ground biomass

- Increase in below-ground biomass.

\subsubsection{Biopolymer}

Some beneficial soil microbes produce and excrete exopolysaccharides (EPS) into the soil around roots. The EPS alter the soil to produce an environment that favors both plant and microbial growth (Bais et al. 2006). By performing the EPS production industrially (Newman et al. 2010, Patent No. 7,824.569) and applying the concentrated EPS to soils, the soil modification that would naturally occur over hundreds of years of leguminous plant/microbe EPS production can be performed in hours.

The EPS of Rhizobium tropici has been field-tested in upland situations and has been shown to decrease erosion on slopes, such as berms and levees (Larson et al. 2012, 2016). In addition, soil amendment with the biopolymer encourages rapid seed germination and root development of desirable grasses over that of invasive species (Larson et al. 2012). It also aids in drought resistance of the plants which means lower maintenance costs for the installation (Muller 2015). Agriculturally, the biopolymer amendment is associated with increased crop yields ${ }^{1}$. The effect of a single application performed during normal soil preparation/seeding practices has been observed to last for several years ${ }^{2}$.

Biopolymer amendment increases soil carbon through the following:

- Reduced soil carbon loss through erosion

- Direct addition of biopolymer carbon to the soil

- Increase in above-ground biomass

- Increase in below-ground biomass.

\subsection{Nitrogen deposition}

Nitrogen deposition from vehicle emissions, air and water pollution is a widespread and growing concern that is not easily managed. However, the impacts of this addition to soils must be understood and managed to

\footnotetext{
$1 \mathrm{~S}$. Sevinc, unpublished communication.

2 S. Larson, USACE ERDC EL, Vicksburg, MS, pers. comm., July 2016. Field study research was conducted in Edwards, MS.
} 
effectively maximize soil carbon storage. Increased nitrogen favors competitive, less desirable, annual plants and weeds, alters plant litter quality, and accelerates nutrient cycling in soils. Ectomycorrhizal diversity in soils has also been shown to drop in areas where nitrogen is deposited due to plants' ability to acquire nitrogen without the cost to associate with their symbiont. In certain instances, this loss of diversity has had detrimental impacts on plant communities, as subsequent droughts have resulted in high plant mortality and community shifts because the symbionts are not present to improve water acquisition, another beneficial function of these fungi (Allen et al. 2010). The reduced vegetative mass could allow an increase in soil carbon loss through erosion. Better ecosystem model development incorporating nitrogen inputs (e.g., fertilizer, deposition), atmospheric carbon levels, and land management will provide more realistic predictive model outputs (Clemmensen et al. 2013). 


\section{Wetland Management Effects on Soil Carbon Flux}

The carbon sequestered in freshwater or coastal wetlands sediment is known colloquially as blue carbon. Coastal vegetation includes both marshes, seagrass and mangrove stands (Figure 7). Wetlands are a dynamic system of carbon sequestration and emission (i.e., carbon flux). Issues that affect sequestration of carbon in sediments include the identification of factors which might limit carbon emission from these sediments as well as those factors which might increase carbon sequestration (Downing et al. 2008).

Figure 7. Examples of coastal vegetation: marshes (top left), mangrove stand (bottom left) and beach grass (right).
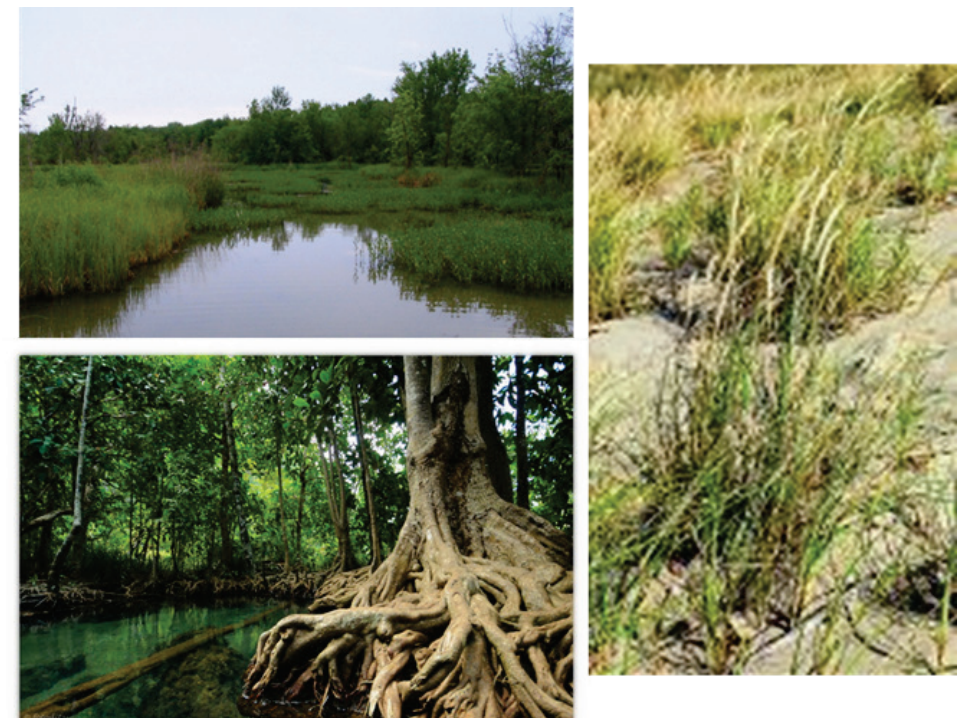

Table 7 compares the sequestration potential of coastal vegetation to that of terrestrial forests. In this summary, sequestration is defined as the burial and storage of carbon in the soil/sediment. Although the carbon saturation potential of wetlands is considered low compared to forests, the sequestration rate and carbon permanence are very high(FAO 2005; MacDicken 2015). A later study also stated that, among LULC classes, wetlands have the highest mean SOC stocks while rangelands have the lowest (West et al. 2013). However, the total area of wetlands is much lower than that of forests and loss of wetlands continues to increase. The high potential for self-expansion implies that if this loss trend is reversed, the plant growth would continue with minimal assistance, and carbon 
sequestration would also increase. The total wetland acreage managed by the USACE, combined with DoD-managed freshwater and, particularly, coastal wetlands, has a very high potential for long-term sequestration of atmospheric carbon.

Table 7. Comparison of carbon sequestration characteristics of coastal vegetation and terrestrial forests.

\begin{tabular}{|c|c|c|}
\hline Characteristic & Coastal vegetation & Terrestrial forest \\
\hline $\begin{array}{l}\text { Sequestration rate, avg } \\
\left(\mathrm{gC} \mathrm{m}^{-2} \mathrm{yr}^{-1}\right)\end{array}$ & $\begin{array}{l}\text { High } 1,2 \\
\text { Marsh } 210^{3} \\
\text { Mangrove } 139 \\
\text { Seagrass } 83^{4}\end{array}$ & \begin{tabular}{|l|} 
Lower1,2 \\
Tropical 2 \\
Temperate 1-12 \\
Boreal 1-2
\end{tabular} \\
\hline Sequestration permanence & High $1-4$ & Low $^{1 ; 2}$ \\
\hline Fire risk & None to low ${ }^{2}$ & High $^{2}$ \\
\hline Carbon saturation potential & Low $^{1-4}$ & High $^{1 ; 2}$ \\
\hline Area & Low $^{1 ; 2}$ & High $^{5}$ \\
\hline Recent loss rate and trend & 1-5\% $\mathrm{yr}^{-1}$, increasing ${ }^{1 ; 2 ; 7}$ & $\begin{array}{l}0.8 \% \mathrm{yr}^{-1}, \text { stable or } \\
\text { decreasing }\end{array}$ \\
\hline $\begin{array}{l}\text { Self-expansion potential (via } \\
\text { unassisted clonal expansion) }\end{array}$ & High/rapid 4;9 & Low \\
\hline
\end{tabular}

1 Laffoley and Grimsditch (2009)

2Nellemann et al. (2009)

${ }^{3}$ Chmura et al. (2003)

${ }^{4}$ Duarte et al. (2005, 2010)

5IPCC (2013)

7Polidoro et al. (2010)

8 FAO Global Forest Resources Assessment (2005)

9 Liu et al. (2007)

As an example, the USACE, and other public and private organizations, are currently spending large amounts of money over several years to restore Gulf of Mexico barrier islands, coastal harbors, vegetated storm barrier areas and brackish and freshwater wetlands (United States Department of Agriculture (USDA), Natural Resources Conservation Service 2003, 2011, Alabama Dune Resoration Project Phase 1 2012). Re-vegetation of these saline and brackish areas is a challenge. However, according to Restore the Earth's proprietary EcoMetrics model, $\$ 1$ of investment in wetlands restoration produces $\$ 9$ of value (http://restoretheearth.org). That value comes in the form of everything from tangibles like water and carbon credits, sustainable timber harvests, and hunting licenses to more difficult-to-value benefits like strengthened social bonds from fishing trips (Boynton 2016). Considering this return-on-investment, it becomes economically advantageous to consider wetlands restoration (Enwright et al. 2016). 


\section{Instigating and Maintaining Changes in Land Management that Promote Carbon Sequestration}

Change is a necessary part of life, but change is difficult. Up to $70 \%$ of all change initiatives fail (Ashkenas 2013). Increasing the mass of atmospheric carbon that is sequestered in soil will require changes in facility land management protocols at both the personal and the organizational level. Attempts to implement new programs, practices, or policies in organizations often fail because leaders do not establish sufficient organizational readiness for change (Kotter 1996). While change management experts have suggested some strategies for creating readiness for change within an organization, there has been limited research in this area.

Disruptive, transformative technologies are being introduced at an accelerating pace that increases individual fear and resistance to change (Juma 2016). Transparency, inclusiveness, and caution in the handling of scientific uncertainty are critical elements of public trust (Juma 2016). How they are managed can increase or decrease the public resistance to technological innovation (change). Objections to change can fall into one, or more, of the following categories:

- Intuitive responses - reflects patterns of behavior that rely on deep evolutionary roots of fears and phobias, such as fears of new foods.

- Vested interests - a clash of competing economic world views and moral values.

- Intellectual challenges -includes philosophical objections to new technologies such as the manipulation of nature.

- Business models - changes can face strong opposition and include some vested interests.

Therefore, successful change requires inclusive innovation for acceptance of new controversial technologies. Ultimately, the goal is to manage public risk perception and foster trust between the public and companies/institutions that introduce innovative technologies. Inclusive innovation means:

- More timely scientific assessments of the benefits and risks of new technologies, 
- Faster adjustment of social institutions to keep pace with the new technologies,

- Greater public awareness and citizen engagement,

- Inclusive economic changes including training in the new technologies by public institutions, equitable management of intellectual property rights, and creation and support of long-term technology partnerships, and

- Building local capabilities in technology adoption and development.

\subsection{Organizational readiness for change}

Figure 8 summarizes Organizational Readiness to Change (ORC), as adapted from Weiner (2009). The ORC is a multi-level, multi-faceted, shared psychological state in which organization members feel committed to implementing an organizational change and confident in their collective abilities to do so (Weiner 2009). Change commitment reflects the shared resolve to implement change. Change efficacy refers to this shared belief in the collective capability to organize and execute the courses of action involved in change implementation. Organizational readiness varies as a function of how much individual members value the change and how favorably they view the task demands, resource availability and situational factors involved in the change. Kotter (1996) suggests that failure to establish sufficient readiness within the organization accounts for $50 \%$ of all unsuccessful large-scale organizational change efforts.

\subsubsection{Change commitment}

According to research of Weiner (2009), members of the organization commit to implementation of change for the following reasons:

- They "want to" - They value the change on a personal level.

- They "have to" - They have little choice about the change.

- They "ought to" - They feel obligated to change.

Members whose commitment to change is based on "want to" rather than "have to" or "ought to" motives exhibit both more cooperative behaviors, such as volunteering, and also championing behavior, such as promoting the value of the change to others (Weiner 2009). 
Figure 8. Factors involved in determining Organizational Readiness for Change (ORC).

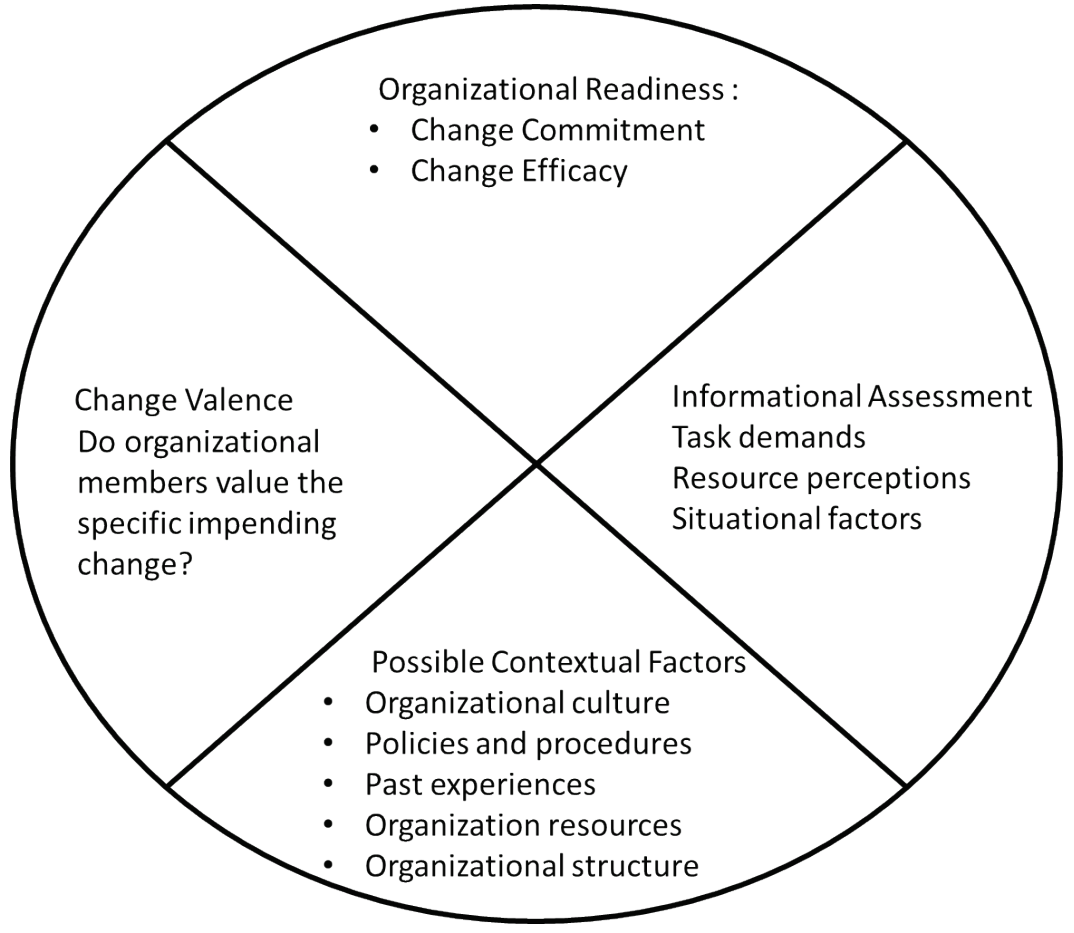

Strategies to enhance change commitment include the following:

- Highlighting the discrepancies between current and desired performance levels

- Encouraging dissatisfaction with the status quo

- Creating an appealing vision of the future state of the organization.

When an organizations members are more likely to initiate change, they exert more effort and persistence in improving the situational factors (such as information availablility, task demands, resources) that oppose that change. These members show increased cooperative behaviors in this regard. Those members who see the change as undesirable often avoid the steps required to implement the change, resist change efforts and may even sabotage change efforts (Kotter and Schlesinger 2008).

\subsubsection{Change efficacy}

Weiner (2009) discussed organizational change efficacy as a shared belief by members of the organization in their collective capablity to implement change. It is a cognitive appraisal of the individuals in a group where members assess, aquire, assimilate, and integrate information that addresses these basic questions: 
- Task demands:

- What are the mechanical steps to success?

$\circ$ Do we know what it will take to implement this change effectively?

- Resource availability (human, financial, material, and information):

- Do we have the resources we need to implement this change effectively?

- Situational factors (sufficient time, internal political environment)?

- Can we implement this effictively given the current situation we face?

Strategies to enhance change efficacy include promoting positive assessments of task demands, available resources and other situational factors.

\subsubsection{Change valence}

Shea et al. (2014) defined change valence as a hypothesized determinant of change commitment. That is, do the members of the organization value the change? Do they believe the change is needed, important, beneficial, or worthwhile? Is the change a part of the core value system of the organization?

How much the change is valued is more important than why it is valued. An unknown in change valence is whether the reasons for supporting a change must match across individual organizational members. Positive change valence resulting from individuals' disparate reasons might be just as potent a determinant of change commitment as change valence resulting from commonly shared reasons.

The true measure of change valence, then, is the question (Shea et al. 2014)

"Regardless of their individual reasons, do organizational members collectively value the change enough to commit to its implementation?” 
Increasing the change efficacy of an organization increases the change valence and, thus, increases the organizational readiness to implement change (Shea et al. 2014).

\subsubsection{Change factors}

In addition to the factors mentioned previously that affect change efficacy, factors concerning the organization itself may affect an individuals commitment to change (Shea et al. 2014). These include the organizations current culture, policies and procedures, past experience with implementing change, its resources that it can allocate to implementing a change, and the structure of the organization. These directly impact training and information sharing, task demands, and resource availability, all considered critical factors of successful change.

\subsection{Organizational Readiness to Implement Change (ORIC)}

Organizational Readiness to Implement Change (ORIC) is a psychometric assessment tool developed by Shea et al. (2014). The assessment helps organizations understand how ready they are to implement change. This directly affects how likely a major change might be accomplished in a complex, multi-level organization. The test is a measure of the change valence and change efficacy of an organization. Its use highlights areas where the organization can improve its performance if change is to be implemented successfully. For example, are a number of responses indicating overwhelming task demands on limited resources or information? This will discourage change commitment by even the positive members and decrease change valence. Increasing information and resources dedicated to the change and shifting personnel responsibilities to equitably share task demands will decrease the negative perceptions, increase the change valence and increase the chance of succesful change implementation. The ORIC test (adapted from Shea et al. 2014 ) is presented as Appendix A.

\subsection{Change for soil carbon sequestration and the DoD}

Understanding DoD readiness for meaningful and significant carbon footprint change from previously accepted protocols and mindsets is an essential element of achieving a statistically significant, sustainable, carbon neutral stance. The organizations' commitment to that mandate must be assessed and re-assessed as carbon neutral-promoting activities 
and technologies are advanced. The ORIC evaluation test (Shea et al. 2014) in Appendix A could be used over time to measure the DoD's continuing commitment to carbon neutrality.

The ORIC test would be ideal for these assessments because it is:

- Brief

- Change independent

- Group referenced

- Amenable to multiple respondents from the entire organization

- Inter-rated agreement

- Valid and reliable.

The ORIC evaluation would assess the change valence (commitment) of both specific DoD facilities, and across the DoD generally, to the idea of carbon neutrality. The evaluation itself might change a number of "have to" and "ought to" individuals to "want to" persons. The ORIC evaluation would also point out weak areas supporting change efficacy. This evaluation might change the DoD's assessment of its task demands, resources and other situational factors. Changes in these areas might contribute to increased chances for successful change implementation. The ORIC data may be used to alter presentations and information sharing and rollout initiatives to maximize the likelihood of successful change. 


\section{Research Areas to Maximize Carbon Sequestration on DoD Lands}

Stockmann et al. (2013) attempted to summarize the "state-of-the-science" concerning sequestration of SOC. Stockmann, and other researchers, agree that it is possible to increase the concentration of carbon stored long-term in soil/sediment as humic material. Potential measures to increase soil carbon include the following:

- Increase the above-ground biomass to include those species that most effectively promote soil carbon sequestration

- Increase forest lands

- Increase perennial plants

- Increase the soil root mass

- Increase the concentration of EPS in the soil,

- Increase the ratio of EMF to AMF in the soil

- Increase total area of wetlands (freshwater, brackish and saline)

- Decrease loss of soil carbon through erosion.

Some specific examples are discussed in the following sections.

\subsection{Stimulation of sequestration using amendments.}

Common commercially available products (i.e., fertilizers and water holding additives like perlite) have shown promise in increasing storage of soil carbon. New products can be developed for this result (such as new biopolymers to improve re-vegetation of salt tolerant species and industrialization of glomalin as a soil amendment). Further, military activities generate unique waste materials (such as biochars or pulverized paper waste) that can be utilized to increase soil carbon in an environmentally friendly manner. Waste management can generate useful soil amendments such as compost or sludge digestates. However, knowledge of where, when, and how much to apply of these amendments is largely lacking. Focused research in this area would result in significant advances in net zero waste and energy objectives while contributing to soil carbon storage. 
Through geoengineering and an understanding of the natural symbiotic relationship between plants and soil microbial communities in the rhizosphere, soils can be rapidly improved with regards to root structure, soil microbial activity, and root carbon exudation. This would lead to increased soil carbon storage and ultimately a healthier soil and soil structure. Costs associated with the production and use of soil amendments could potentially be offset by the following:

- Increased crop yields and reduced crop loss when used in agricultural soils

- Decreased soil loss through erosion when used for berm and levee construction and maintenance

- Increased grazing efficiencies when used with livestock industries

- Increased habitat, flood protection, and water quality when used in wetlands.

\subsection{Stimulation of plant growth in marginal soils}

Brackish wetlands can be very productive, but increasing plant growth in these areas is not well studied. Several EPS producing bacteria are being investigated for use in these marginal, nutrient-poor, and saline environments. There are plant species tolerant of salt that grow as well in saline soils as they do under more normal soil conditions. These plants also have associated rhizosphere bacteria that produce biopolymers and biofilms that appear to protect the plant from salt toxicity (Feagin et al. 2009; Qurashi and Sabri 2011). These include Rhizobium leguminosarum associated with Strawberry clover, several Bradyrhizobium sp. associated with Birdsfoot trefoil, and Mesorhizobium loti. These bacteria produce exopolymers that can be grown in bioreactors. These biopolymers should be evaluated for seed germination and development in marginal soils.

\subsection{Eco-Engineering}

Military lands are already managed to balance training and testing needs with environmental stewardship. However, little consideration is given to maximizing soil carbon content. Fortunately, many of these perspectives are mutually inclusive. Training doctrine and land management require healthy plant communities. Additional knowledge on what traits of healthy plant communities promote the greatest carbon storage and where this knowledge can be applied will have little effect on current training 
requirements while having a potentially large impact on soil carbon storage. Examples include the following:

- Identifying areas where agricultural outleasing can be altered to increase soil carbon storage

- Prioritizing invasive species management efforts towards those that have the most negative impact on soil carbon

- Substituting species in seed mixtures to include greater and deeper root growth

- Identifying soils and other prime areas where carbon storage can be significantly increased

- Optimizing controlled burns to favor soil biological processes that promote carbon storage

- Inclusion of soil ecosystem services in timber management plans.

One of the most overlooked aspects of ecosystems is the biology of soil, including the management of mycorrhizal fungi that are vital in multiple ecosystem processes. In grasslands and shrublands, the AMF dominate (Sabais et al. 2012). Identifying mycorrhizal associations that increase glomalin and extra-radicle hyphae production would increase carbon storage. In forests, where EMF dominate (Pena et al. 2010), identifying the ideal ratio of ectomycorrhizal to arbuscular mycorrhizal hosts would increase soil carbon storage. An improved understanding of which associations between fungi and plants concomitantly promote a desirable training environment and maximize soil carbon storage would yield simple strategies with large payoffs.

\subsection{The use of biomass for energy production}

It may be possible to couple soil carbon sequestration with alternative energy production to increase the carbon benefit to DoD installations. Biomass at installations may be able to be collected to be used to produce energy. This includes methods like direct incineration, gasification, pyrolysis or anaerobic digestion to produce burnable gases or fuels, as well as extraction of oils and fats for biofuel production (Medina et al. 2003; Medina et al. 2015 is a discussion of approaches for wastewater residuals, but can also be applied for other biomass forms). 


\subsection{ERDC resources and funding vehicles}

There are several avenues for collaboration and funding research into closing these data gaps, including the following:

- The DoD agencies of SERDP and ESTCP

- The USACE Climate Preparedness and Resilience Program

- The NSF NEON program. 


\section{Conclusions}

The USACE has a long history of developing solutions for the nations and the world's most challenging engineering issues. From critical advances in military engineering to protection from floods and promoting navigation, solving the large and difficult challenges through the application of innovative engineering solutions on a large scale has often fallen on the Corps of Engineers. There is a belief that one of the greatest engineering challenges of the future will be the reduction of atmospheric $\mathrm{CO}_{2}$ levels.

In 2014, in conjuction with the Institute for Water Resources, the USACE Climate Preparedness and Resiliency Community of Practice (CPR CoP) was created within the Engineering and Construction CoP. The purpose of the new CPR CoP was

\section{"to increase the individual and organizational abilities and technical competence within USACE to plan, design, engineer and execute work that enhances the climate preparedness and resilience of its partners and stakeholders."}

UASCE climate change preparedness and resilience information (2014) can be accessed at http://www.corpsclimate.us.

Compared to engineering projects such as solar mirrors and pumping atmospheric carbon deep into the earth, soil carbon sequestration through changes in land management strategies is one of the few atmospheric carbon reduction efforts that could be implemented relatively quickly, over a large scale, and potentially at low cost. This CASI white paper has attempted to summarize the major impacts of DoD land use management methods on carbon flux and the human element of strategy implementation. This information can be used to better guide planning and accounting of environmental compliance activities. Additionally, while existing products and models are incapable of accurately estimating carbon fluxes on military lands, the unique nature of these activities should warrant focused research to develop accurate sequestration models. This proactive approach will help determine what future follow-on efforts might be necessary to fully understand carbon fluxes on military lands, including potential planning and policy guidance and research and 
development efforts. Recommendations put forward by this white paper identify specific research needs in these areas.

\subsection{Is it possible to achieve carbon neutral status on DoD managed lands and facilities?}

Yes, with qualifications. While small changes in the SOC stock could result in significant impacts on the atmospheric carbon concentration (Stockmann et al. 2013), land management change may not happen quickly. Considering just a single land management change, such as the use of biopolymers as a soil management tool, how effective could this approach be for reducing atmospheric carbon? The University of Manchester carbon sequestration calculator (http://dbkgroup.org/carbonsequestration/rootsystem.html) was used to consider this question on a global scale:

- The amount of carbon as $\mathrm{CO}_{2}$ currently in the atmosphere is approximately $750 \mathrm{Pg}$, and that in the soil is approximately $1,500 \mathrm{Pg}$.

- If the global land area for crops is 2,300 Mha and that for grassland is 2,300 Mha, and an extra 1.0 m depth of roots are grown, and they take up $1.0 \%$ (by mass at an equivalent carbon density of $1,000 \mathrm{~kg} \mathrm{~m}^{-3}$ ) of the relevant soil volume, then the extra amount of carbon that could be sequestered by the above land areas is $10 \mathrm{~kg} \cdot \mathrm{m}^{-2}=100 \mathrm{t}^{-} \mathrm{ha}^{-1}$.

- This equates to $230 \mathrm{Pg}$ (230,000 M tons), if the carbon in the roots and other sequestered carbon are re-respired over a period of two years.

- As $1 \mathrm{Pg}$ is equivalent to $0.51 \mathrm{ppmv}$ of atmospheric $\mathrm{CO}_{2}$, this would decrease the $\mathrm{CO}_{2}$ in the atmosphere by $118 \mathrm{ppmv}$; the current value of $385 \mathrm{ppmv}$ would decrease to $267 \mathrm{ppmv}$. This represents a $31 \%$ reduction in atmospheric $\mathrm{CO}_{2}$ after two years.

Obviously there are numerous assumptions leading to the calculated results, and significant effort would be required to produce a more meaningful prediction of the reduction of atmospheric $\mathrm{CO}_{2}$. Beyond that, the inclusion of reductions of atmospheric $\mathrm{CO}_{2}$ levels would need to be incorporated into advanced climate models in order to evaluate the technology's actual effectiveness. However, the possibility of such a reduction should merit the further evaluation of changes in land management strategies to increase soil carbon for climate protection. 


\subsection{Could DoD facilities be useful for carbon banking?}

Yes, but with larger qualifications. The size of these areas could yield substantial carbon offsets. However, a carbon banking system has not yet been set up in the United States. Further, it would be necessary to explore if there are any regulatory restrictions to DoD facilities participating in carbon trading programs. 


\section{References}

Adams, J. 2016. Oak Ridge National Laboratory, Environmental Sciences Division introductory page. https://www.ornl.gov/division/esd. Accessed 19 September 2016.

AECOM. 2013. The Impact of Climate Change and Population Growth on the National Flood Insurance Program Through 210o. Federal Emergency Management Agency (FEMA), Washington, DC.

Ahmed, I. U., A. R. Smith, D. L. Jones and D. L. Godbold. 2016. Tree species identity influences the vertical distribution of labile and recalcitrant carbon in a temperate deciduous forest soil. Forest Ecology and Management 359:352-360. https://doi.org/10.1016/j.foreco.2015.07.018.

Ahmedna, M., W. E. Marshall, R. M. Rao. 200o. Production of granular activated carbons from select agricultural by-products and evaluation of their physical, chemical and adsorption properties. Bioresource Technologies 71(2): 113-123. https://doi.org/10.1016/S0960-8524(99)00070-X.

Alabama Dune Restoration Project. Phase I Early Restoration Plan. 2012. Coastal Alabama Dune Restoration Cooperative. Available online: http://www.gulfspillrestoration.noaa.gov/alabama-dune-restoration-cooperative-project. (Accessed September 2016).

Alexandrov, G. A. 2007. Carbon stock growth in a forest stand: The power of age. Carbon Balance Management 2:4. doi: 10.1186/1750-0680-2-4.

Allen, M. F., E. B. Allen, J. L. Lansing, K. S. Pregitzer, R .L. Hendrick, R. W. Ruess and S. L. Collins. 2010. Responses to chronic N fertilization of ectomycorrhizal piñon but not arbuscular mycorrhizal juniper in a piñon-juniper woodland. Journal of Arid Environments 74(10):1170-1176. https://doi.org/10.1016/j.jaridenv.2010.05.001.

Anna, C. 2009. The forest and fungi: Studying the effects of prescribed burning on mycorrhizal fungi in Crater Lake National Park. Joint Fire Service Program (JFSP) Briefs, Paper 61. University of Nebraska-Lincoln.

Ashkenas, R. 2013. Change management needs to change. Harvard Business Review, April. http://hbr.org/2013/04/change-management-needs-to-change.

Averill, C., B. L. Turner and A. C. Finzi. 2014. Mycorrhiza-mediated competition between plants and decomposers drives soil carbon storage. Nature 505 (7484):543-545. doi: 10.1038/nature12901.

Bais, H. P., T. L. Weir, L. G. Perry, S. Gilroy, and J. M. Vivanco. 2006. The role of root exudates in rhizosphere interactions with plants and other organisms. Annual Review of Plant Biology 57: 233-266. https://doi.org/10.1146/annurev.arplant.57.032905.105159

Bockheim, J. 2007. Soil processes and development rates in the Quartermain Mountains, upper Taylor Glacier region, Antarctica. Geografiska Annaler Series A-Physical Geography 89: 153-165. 
Boynton, J. 2016. Louisianna wetlands restoration project offers corporate investors a social return. TriplePundit, http://www.triplepundit.com/2016/07/louisiana-wetlandsrestoration-social-return-investment/\#

Brzostek, E. R., D. Dragoni, Z. A. Brown and R. P. Phillips. 2015. Mycorrhizal type determines the magnitude and direction of root-induced changes in decomposition in a temperate forest. New Phytologist 206:1274-1282.

Bundt, M., F. Widmer, M. Pesaro, J. Zeyer, and P. Blaser. 2001. Preferential flow paths: biological "hot spots" in soils. Soil Biology and Biochemistry 33:729-738.

Burke, E. J., I. P. Hartley, and C. D. Jones. 2012. Uncertainties in the global temperature change caused by carbon release from permafrost thawing. The Cryosphere 6: 1063-1076. doi: 10.5194/tc-6-1063-2012.

Busby, R. R., D. L. Gebhart, M. E. Stromberger, P. J. Meiman, and M. W. Paschke. 2011. Early seral plant species' interactions with an arbuscular mycorrhizal fungi community are highly variable. Applied Soil Ecology 48: 257-262.

Busby, R. R., M. E. Stromberger, G. Rodriguez, D. L. Gebhart, and M. W. Paschke. 2013. Arbuscular mycorrhizal fungal community differs between a coexisting native shrub and introduced annual grass. Mycorrhiza 23:129-141.

Canadell, J., R. B. Jackson, J. R. Ehleringer, H. A. Mooney, O. E. Sala and E. D. Schulze. 1996. Maximum rooting depth of vegetation types at the global scale. Oecologia 108:583-595.

Canadell, P. 2007. Carbon Balance and Terrestrial Vulnerabilities. Presentation, Earth System Feedbacks: Vulnerability of the Carbon Cycle to Drought and Fire, Canberra, Australia, June 2006. Accessed January 2017. http://www.globalcarbonproject.org/.

Cernansky, R. 2016. Guardian of a hidden universe. Nature 537: 298-300.

Chabbi, A., I. Kögel-Knaber, and C. Rumpel. 2009. Stabilised carbon in subsoil horizons is located in spatially distinct parts of the soil profile. Soil Biology and Biochemistry 41: 256-261. doi: 10.1016/j.soilbio.2008.10.033.

Chmura, G. L., S. C. Anisfeld, D. R. Cahoon, and J. C. Lynch. 2003. Global carbon sequestration in tidal, saline wetland soils. Wetlands 17:1111.

Clemmensen, K. E., A. Bahr, O. Ovaskainen, A. Dahlberg, A. Ekblad, H. Wallander, J. Stenlid, R. D. Finlay, D. A. Wardle, and B. D. Lindahl. 2013. Roots and associated fungi drive long-term carbon sequestration in boreal forest. Science 339:16151618.

CNA Military Advisory Board. 2014. National Security and the Accelerating Risks of Climate Change. Alexandria, VA: CNA Corporation.

Conant, R. T., and K. Paustian. 2002. Spatial variability of soil organic carbon in grasslands: implications for detecting change at different scales. Environmental Pollution 116:127-135. 
Conant, R.T., G. Smith, and K. Paustian. 2003. Spatial variability of soil carbon in forested and cultivated sites: implications for change detection. Journal of Environmental Quality 32: 278-286.

Conen, F., M. Yakutin and A. Sambuu. 2003. Potential for detecting changes in soil organic carbon concentrations resulting from climate change. Global Change Biology 9: 1515-1520.

Conen, F., A. Zerva, D. Arrouays, C. Jolivet, P. G. Jarvis, J. Grace, and M. Mmencuccini. 2004. The carbon balance of forest soils: detectability of changes in soil carbon stocks in temperate and boreal forests. In: The Carbon Balance of Forest Biomes (eds. Griffith H, Jarvis PG) Bios Scientific Press, London.

Council on Environmental Quality. 2016. Federal Greenhouse Gas Accounting and Reporting Guidance., Washington, DC. https://www.gsa.gov/portal/getMediaData?medialD=158510. (Accessed June 2017).

de Gruijter, J., D. J. Brus, M. F. P. Bierkens, and M. Knotters. 2006. Sampling for Natural Resource Monitoring. Springer-Verlag.

Delwiche, J. 2009. Post-fire soil erosion and how to manage it. Joint Fire Service Program (JSFP) Briefs. Paper 59. http://digitalcommons.unl.edu/ifspbriefs/59. (Accessed September 2016).

Department of the Army (DoA). 2010. Exterior lighting technologies policy. memorandum. http://www.armyenergy.hqda.pentagon.mil/policies/docs/exterior_lighting_technologies_policy.pdf

Donovan, P. 2013. Measuring soil carbon change. A flexible, practical, local method. http://soilcarboncoalition.org/files/MeasuringSoilCarbonChange.pdf. (Accessed June 2016).

Downing, J. A., J. J. Cole, J. J. Middleburg, R. G. Striegl, C. M. Durarte, P. Kortelainen, Y. T. Prairie, and K. A. Laube. 2008. Sediment organic carbon burial in agriculturally eutrophic impoundments over the last century. Global Biogeochemical Cycles 22. doi:1010.1029/2006GBo02854.

Duarte, C., J. Middelburg, and N. Caraco. 2005. Major role of marine vegetation on the oceanic carbon cycle. Biogeosciences 2, 1-8.

Duarte, C. M., N. Marbà, E. Gacia, J. W. Fourqurean, J. Beggins, C. Barrón, and E. T. Apostolaki. 2010. Seagrass community metabolism: assessing the carbon sink capacity of seagrass meadows. Global Biogeochem Cycles 24(4):4032. doi:10.1029/2010GBoo3793.

Ekblad, A., H. Wallander, D. L. Godbold, C. Cruz, D. Johnson, P. Baldrian, R. G. Bjork, E. Epron, B. Kieliszewska-Rokicka, R. Kjoller, H. Kraigher, E. Matzner, J. Neumann and C. Plassard. 2013. The production and turnover of extrametrical mycelium of ectomycorrhizal fungi in forest soils: role in carbon cycling. Plant and Soil 366:127.

Enwright, N. M., K. T. Griffith, and M. J. Oslund. 2016. Barriers to and opportunities for landward migration of coastal wetlands with sea-level rise. Frontiers in Ecology and the Environment 14: 307-316. 
Executive Office of the President. 2013. The President's Climate Action Plan. The White House. Washington, D.C.

Fang, Y., B. Singh, B. P. Singh, and E. Krull. 2014. Biochar stability in four contrasting soils. European Journal of Soil Science 65: 60-71.

FAO (Food and Agriculture Organization). 2005. Global Forest Resource Assessment 2000. Rome, Italy.

Feagin, R. A., S. M. Lozada-Bernard, T. M. Ravens, I. Möller, K. M. Yeager, and A. H. Baird. 2009. Does vegetation prevent wave erosion of salt marsh edges? In Proceedings of the National Academy of Sciences, USA. 106: 10109-10113. DOI: 10.1073/pnas.0901297106

Fontaine, S., S. Barot, P. Barre, N. Bdioui, B. Mary, and C. Rumpel. 2007. Stability of organic carbon in deep soil layers controlled by fresh carbon supply. Nature 450:277-281.

Fornara, D. A., and D. Tilman. 2008. Plant functional group composition influences rates of soil carbon and nitrogen accumulation. Journal of Ecology 96:314-322.

Fornara, D. A., and D. Tilman. 2012. Soil carbon sequestration in prairie grasslands increased by chronic nitrogen addition. Ecology 93:2030-2036.

Friedlingstein, P., M. Meinshausen, V. K. Arora, C. D. Jones, A. Anav, S. K. Liddicoat, and R. Knutti. 2014. Uncertainties in $\mathrm{CMIP}_{5}$ climate projections due to carbon cycle feedbacks. Journal of Climate 27: 511-526. doi: 10.1175/JCLI-D-12-00579.1.

Garcia-Palacios, P., F. T. Maestre, J. Kattge, and D. H. Wall. 2013. Climate and litter quality differently modulate the effects of soil fauna on litter decomposition across biomes. Ecology Letters 16: 1045-1053. doi: 10.1111/ele.1213.

Garcia-Palacios, P., F. T. Maestre, J. Kattge, and D. H. Wall. et al. 2013. Corrigendum to Garcia-Palacios et al. EcologyLetters 16: 1418. DOI: 10.1111/ele.12179.

Garten C., and S. Wullscheleger. 1999. Soil carbon inventories under a bioenergy crop (Switchgrass): Measurement limitations. Journal of Environmental Quality 28: 1359-1365.

General Accounting Office (GAO). 2009. Alaskan Native Villages. Limited Progress has been made on Relocating Villages Threatened by Flooding and Erosion. GAO09-551, Washington, DC.

Grayston, S. J., D. Vaughan and D. Jones. 1996. Rhizosphere carbon flow in trees, in comparison to annual plants: The importance of root exudation and its impact on microbial activity and nutrient availability. Applied Soil Ecology 5:29-56.

Hendricks, J. J., R. J. Mitchell, K. A. Kuehn and S. D. Pecot. 2016. Ectomycorrhizal fungal mycelia turnover in a longleaf pine forest. New Phytologist 209:1693-1704.

Herrman, V. 2015. Alaskan Villages Imperiled by Global Warming Need Resources to Relocate. The Guardian. New York, NY. http://gu.com/p/4aqdd/stw 
Homer, C. G., J. A. Dewitz, L. Yang, S. Jin, P. Danielson, G. Xian, J. Coulston, N. D. Herold, J. D. Wickham and K. Megown. 2015. Completion of the 2011 National Land Cover Database for the conterminous United States-Representing a decade of land cover change information. Photogrammetric Engineering and Remote Sensing 81:345-354.

Hurteau, M. D., and M. L. Brooks. 2011. Short- and long-term effects of fire on carbon in U.S. dry temperate forest systems. BioScience 61:139-146.

Intergovernmental Panel on Climate Change (IPCC). 2013. Summary for Policymakers, in Climate Change 2013: The Physical Science Basis, Contribution of Working Group I to the Fifth Assessment Report of the Intergovernmental Panel on Climate Change, Eds. T. F. Stocker, D. Qin, G. K. Plattner, M. Tignor, S. K. Allen, J. Boschung, A. Nauels, Y. Xia, V. Bex, and P. M. Midgley, Cambridge University Press, Cambridge.

Jackson, R. B., J. Canadell, J. R. Ehleringer, H. A. Mooney, O. E. Sala and E. D. Schulze. 1996. A global analysis of root distributions for terrestrial biomes. Oecologia 108:389-411.

Jenkinson, D. S., and K. Coleman. 2008. The turnover of organic carbon in subsoils. Part 2. Modeling carbon turnover. European Journal of Soil Science 59: 400-413. doi: 10.1111/j.1365-2389.2008.01026.x.

Jobbagy, E. G., and R. B. Jackson. 2000. The vertical distribution of soil organic carbon and its relation to climate and vegetation. Ecological Applications 10:423-436.

Jones, D. L., A. Hodge and Y. Kuzyakov. 2004. Plant and mycorrhizal regulation of rhizodeposition. New Phytologist 163:459-480.

Jones R. J. A., and F. G. A. Verheijen. 2008. Procedures and Protocols. Final Report, ENVASSO Project (Contract 022713) coordinated by Cranfield University, UK, for Scientific Support to Policy, European Commission 6th Framework Research Programme.

Juma, C. 2016. Innovation and Its Enemies: Why People Resist New Technologies. Oxford University Press.

Kellndorfer, J., W. Walker, E. LaPoint, J. Bishop, T. Cormier, G. Fiske, M. Hoppus, K. Kirsch and J. Westfall. 2012. NACP Aboveground Biomass and Carbon Baseline Data (NBCD 2000), U.S.A., 2000. Data set. Available on-line at http://daac.ornl.gov from ORNL DAAC, Oak Ridge, Tennessee, U.S.A. http://dx.doi.org/10.3334/ORNLDAAC/1081.

Kong, A. Y. Y., J. Six, D. C. Bryant, R. F. Denison, and C. van Kessel. 2005. The relationship between carbon input, aggregation, and soil organic carbon stabilization in sustainable cropping systems. Soil Science Society of America Journal 69: 1078-1085. doi: 10.2136/ssaj2004.2015

Koteen, L. E., D. B. Baldocchi and J. Harte. 2011. Invasion of non-native grasses causes a drop in soil carbon storage in California grasslands. Environmental Research Letters 6:1-10.

Kotter, J. P. 1996. Leading Change. Boston: Harvard Business Press. 
Kotter, J. P., and L. A. Schlesinger. 2008. Choosing Strategies for Change. Harvard Business Review. Reprint Ro807M.

Koven, C. D., W. J. Riley, Z. M. Subin, J. Y. Tang, M. S. Torn, W. D. Collins, G. B. Bonan, D. M. Lawrence, and S. C. Swenson. 2013. The effect of vertically resolved soil biogeochemistry and alternate soil $\mathrm{C}$ and $\mathrm{N}$ models on C dynamics of CLM4. Biogeosciences 10: 7109-7131. doi: 10.5194/bg-10-7109-2013.

Kristensen, E., G. Penha-Lopes, M. Delefosse, T. Valdemarsen, C. O. Quintana and G. T. Banta. 2012. What is bioturbation? The need for a precise definition for fauna in aquatic sciences. Marine Ecology Progress Series, 446: 285-302, doi: 10.3354/mepso9506.

Laffoley, D. A., and G. Grimsditch. 2009. The Management of Natural Coastal Carbon Sinks. IUCN, Gland, Switzerland.

Lal, R. 2010. Managing soils and ecosystems for mitigating anthropogenic carbon emissions and advancing global food security, BioScience 60: 708-721.

Lark R. M., P. H. Bellamy, and B. G. Rawlins. 2006. Spatio-temporal variability of some metal concentrations in the soil of eastern England, and implications for soil monitoring. Geoderma 133: 363-379.

Larson, S. L., J. K. Newman, C. S. Griggs, M. Beverley and C. C. Nestler. 2012. Biopolymers as an Alternative to Petroleum-Based Polymers for Soil Modification. Treatability Studies. ERDC TR-12-8. Vicksburg MS: U.S. Army Engineer Research and Development Center.

Larson, S. L. 2016. Bioengineered material for erosion control. Flood Risk Management Newsletter 9: 9.

Larson, S. L., G. Nijak, Jr., M. Corcoran, E. Lord, and C. Nestler. 2016. Evaluation of Rhizobium tropici-derived Biopolymer for Erosion Control of Protective Berms. Field Study: Iowa Army Ammunition Plant. ERDC TR-16-5. Vicksburg MS: U.S. Army Engineer Research and Development Center.

Laspidou, C. S., and B. E. Rittmann. 2002. A unified theory for extracellular polymeric substances, soluble microbial products, and active and inert biomass. Water Research 36: 2711-2720.

Lauenroth, W. K., and R. Gill. 2003. Turnover of root systems. Pages 61-89 in Root Ecology. Eds.de Kroon, H. and E. J. W. Visser. Ecological Studies 168. Springer, Berlin.

Liu, J., T. Dietz, S. R. Carpenter, M. Alberti, C. Folke, E. Moran, A. N. Pell, P. Deadman, T. Kratz, J. Lubchenko, E. Ostrom, Z. Ouyang, W. Provencher, C. L. Redman, S. H. Schneider, and W.W. Taylor. 2007. Complexity of Coupled Human and Natural Systems. Science 317:1513-1516.

Lozar, R. C., M. S. Hiett, J.D. Westervelt, and J. W. Weatherly. 2011. Anticipating Climate Change Impacts on Army Installations. United States Army Engineer Research \& Development Center. ERDC SR-11-1. Vicksburg MS: U.S. Army Engineer Research and Development Center. 
Lundström, U. S., N. van Breeman, D. C. Bain, P. A. W. van Hees, R. Giesler, J. P. Gustafsson, H. Ilvesniemi, E. Karltun, P. -A. Melkerud, M. Olsson, G. Riise, O. Wahlberg, A. Bergelin, K. Bishop, R. Finlay, A. G. Jongmans, T. Magnusson, H. Mannerkoski, A. Nordgren, L. Nyberg, M. Starr, and L. Tau Strand. 2000. Advances in understanding the podzolization process resulting from a multidisciplinary study of three coniferous forest soils in the Nordic countries. Geoderma 94: 335-353.

Luyssaert, S., E. D. Schulze, A. Borner, A. Knohl, D. Hessenmoller, B. E. Law, P. Ciais and J. Grace. 2008. Old-growth forests as global carbon sinks. Nature 455:213-215.

MacDicken, K. G. 2015. Global Forest Resources Assessment 2015: What, why and how? Forest Ecology and Management 352: 3-8. DOI: 10.1016/j.foreco.2015.02.006

Marin-Spiotta, E., O. A. Chadwick, M. Kramer and M. S. Carbonne. 2011. Carbon delivery to deep mineral horizons in Hawaiian rain forest soils. Journal of Geophysical Research 116: Go3011, doi: 10.1029/2010JG001587.

Mathieu, J. A., C. Hatte, J. Balesdent and E. Parent. 2015. Deep soil carbon dynamics are driven more by soil type than by climate: a worldwide meta-analysis of radiocarbon profiles. Global Change Biology 21:4278-4292.

Medina, V. F., S. K. Early, and E. Schmieman. 2003. Modeling Sequestration of Carbon Dioxide from Fossil Fuel Power Plants by Algae Lagoons. Conference Paper. In Situ and On-Site Bioremediation. $7^{\text {th }}$ International Conference. Orlando, FL. https://www.researchgate.net/publication/269930891.

Medina, V. F., R. J. Scholze, S. A. Waisner, and C. S. Griggs. 2015. Energy and Resource Recovery from Wastewater Treatment: State of the Art and Potential Application for the Army and the DoD. ERDC SR-15-2. Vicksburg MS: U.S. Army Engineer Research and Development Center.

Medina, V. F., C. S. Griggs, and C. Thomas. 2016. Evaluation of the Destruction of the Harmful Cyanobacteria, Microcystis aeruginosa, with Cavitation and Superoxide Generating Water Treatment Reactor. Bulletin of Environmental Contamination and Toxicity. 96(6):791-796.

Miller, R. M., D. R. Reinhardt and J. D. Jastrow. 1995. External hyphal production of vesicular-arbuscular mycorrhizal fungi in pasture and tallgrass prairie communities. Oecologia 103:17-23.

Mishra, U., R. Lal, B. Slater, F. Calhoun, D. Liu, and M. van Meirvenne. 2009. Predicting soil organic carbon stock using profile depth distribution functions and ordinary kriging. Soil Science Society of America Journal 73: 614-621.

Muller, K. S. 2015. Cost benefit analysis of biopolymers, petroleum-based polymers, and traditional soil stabilization methods. White Paper 2015-1, United States Military Academy, Center for Nation Reconstruction and Capacity Development, West Point, New York.

Nellemann, C., E. Corcoran, C. M. Duarte, L. Valdes, C. DeYoung, L. Fonesca, and G. Grimsditch. (eds). 2009. Blue carbon: A rapid response assessment. United Nations Environment Programme, GRID-Arendal. 
Newman J. K., D.B. Ringleberg, K. P. O'Connell, W. A. Martin, V. F. Medina, and S. L. Larson. 2010. Soluble Salt Produced From a Biopolymer and a Process for Producing the Salt. USPTO Patent No. 7,824,569.

Nichols, K. A. 2003. Characterization of glomalin: a glycoprotein produced by arbuscular mycorrhizal fungi. Ph.D. Dissertation. University of Maryland, College Park, Maryland.

Paterson, E., A. A. Sim, J. Davidson, and T. Duvall. 2016. Arbuscular mycorrhizal hyphae promote priming of native soil organic matter mineralisation. Plant and Soil 408:243-254. DOI: 10.1007/s11104-016-2928-8.

Pena, R., C. Offermann, J. Simon, P. S. Naumann, A. Geßler, J. Holst, M. Dannenmann, H. Mayer, I. Kögel-Knabner, H. Rennenberg, and A. Polle. 2010. Girdling affects ectomycorrhizal fungal (EMF) diversity and reveals functional differences in EMF community composition in a Beech forest. Applied and Environmental Microbiology 76: 1831-1841. DOI: 10.1128/AEM.01703-09.

Ping, C. L., J. D. Jastrow, M. T. Jorgensen, G. J. Michaelson and Y. L. Shur. 2015. Permafrost soils and carbon cycling. Soil, 1: 147-171. doi: 10.5194/soil-1-147-2015.

Polidoro B. A., K. E. Carpenter, L. Collins, N. C. Duke, A. M. Ellison, J. C. Ellison, Elizabeth J. Farnsworth, E. S. Fernando, K. Kathiresan, N. E. Koedam, S. R. Livingstone, T. Miyagi, G. E. Moore, V. N. Nam, J. E. Ong, J. H. Primavera, S. G. Salmo III, J. C. Sanciangco, S. Sukardjo, Y. Wang, and J. W. Hong Yong. 2010. The loss of species: Mangrove extinction risk and geographic areas of global concern. PLOS ONE 5(4): e10095. doi:10.1371/journal.pone.0010095.

Qurashi, A. W., and Sabri, A. N. 2011. Osmoadaptation and plant growth promotion by salt tolerant bacteria under salt stress. African Journal of Microbiology Research 5(21): 3546-3554. doi: 10.5897/AJMR11.736.

Rasse, D. P., C. Rumpel and M. F. Dignac. 2005. Is soil carbon mostly root carbon? Mechanisms for a specific stabilization. Plant and Soil 269: 341-356, doi 10.1007/s11104-004-0907-y.

Rasse, D. P., J. Mulder, C. Moni and C. Chenu. 2006. Carbon turnover kinetics with depth in a French loamy soil. Soil Science Society of America Journal 70, 2097-2105.

Sabais, A. C., N. Eisenhauer, S. König, C. Renker, F. Buscot, and S. Scheu. 2012. Soil organisms shape the competition between grassland plant species. Oecologia 170: 1021-1032. DOI: 10.1007/s00442-012-2375.

Saby N., and Arrouays D. 2004. Simulation of the use of a soil monitoring network to verify carbon sequestration in soils: will changes in organic carbon stocks be detectable? Soil Science and Plant Analysis 35(17-18): 2379-2396.

Setala, H. M., G. Francini, J. A. Allen, N. Hui, A. Jumpponen and D. J. Kotze. 2016. Vegetation type and age drive changes in soil properties, nitrogen, and carbon sequestration in urban parks under cold climate. Frontiers in Ecology and Evolution 4. doi: 10.3389/fevc.2016.00093. 
Shea, C. M., S. R. Jacobs, D. E. Esserman, K. Bruce, and B. J. Weiner. 2014.

Organizational readiness for implementing change: A psychometric assessment of a new measure. Implementation Science 9. doi: 10.1186/1748-5908-9-7.

Sigua, G. C., J. M. Nval, D. W. Watts, K. B. Cantrell, P. D. Shumaker, A. A. Szögi, M. G. Johnson. 2014. Carbon mineralization in two ultisols amended with different sources and particle sizes of pyrolyzed biochar. Chemosphere 103: 313-321. https://doi.org/10.1016/i.chemosphere.2013.12.024

Smith P. 2004. How long before a change in soil organic carbon can be detected? Global Change Biology 10(11): 1878-1883. doi: 10.1111/j.1365-2486.2004.00854.x.

Solar Energy Industries Association (SEIA). 2013. Enlisting the Sun: Powering the US Military with Solar Energy. Washinton, D.C. http://www.seia.org/sites/default/files/Enlisting\%20the\%20Sun-Final-5.14.13-R6.pdf

Spohn, M., K. Klaus, W. Wanek and A. Richter. 2016. Microbial carbon use efficiency and biomass turnover times depending on soil depth - Implications for carbon cycling. Soil Biology and Biochemistry 96:74-81.

Staddon, P. L., C. B. Ramsey, N. Ostle, P. Ineson and A. H. Fitter. 2003. Rapid turnover of hyphae of mycorrhizal fungi determined by AMS microanalysis of 14C. Science. 300(5622):1138-1140.

Stockmann, U., M. A. Adams, J. W. Crawford, D. J. Field, N. Henakaachchi, M. Jenkins, B. Minasny, A. B. McBratney, V. de Remy de Courcelles, K. Singh, I. Wheeler, L. Abbott, D. A. Angers, J. Baldock, M. Bird, P.C. Brookes, C.Chenu, J. D. Jastrow, R. Lal, J. Lehmann, A. G. O’Donnell, W. J. Parton, D. Whitehead, and M. Zimmerman. 2013. The knowns, known unknowns and unknowns of sequestration of soil organic carbon. Agriculture, Ecosystems and Environment, 164: 80-99.

Todd-Brown, K. E. O., J. T. Randerson, F. Hopkins, V. Arora, T. Hajima, C. Jones, E. Shevliakova, J. Tjiputra, E. Volodin, T. Wu, Q. Zhang, and S.D. Allison. 2014. Changes in soil organic carbon storage predicted by Earth system models during the $21^{\text {st }}$ century. Biogeosciences, 11: 2341-2356. doi: 10.5194/bg-11-2341-2014.

Trumbore, S. 2009. Radiocarbon and soil carbon dynamics. Annual Review of Earth and Planetary Sciences, 37: 47-66. doi:

10.1146/annurev.earth.36.03.031207.124300.

United States Army Corps of Engineers (USACE). 2006. Kivalina, Alaska. Relocation Planning Project Master Plan. Alaska District. http://web.law.columbia.edu/sites/default/files/microsites/climate-change/files/ArcticResources/Relocation-Plans/USACE\%20relocation\%20plan\%20Kivalina\%20exec\%20sum.pdf.

United States Army Corps of Engineers (USACE). 2014. Responses to climate change: Preparedness and resilience. http://www.corpsclimate.us. (Accessed July 2017).

United States Department of Agriculture, Natural Resources Conservation Service (NRCS), Wetland Science Institute. 2003. Wetland restoration, enhancement, and management. Paper 143, Washington, DC. Available on-line, http://www.nrcs.usda.gov/internet/FSE_DOCUMENTS/nrcs143_010838.pdf 
United States Department of Agriculture, Natural Resources Conservation Service (NRCS). 2011. Coastal shoreline and dune restoration. Technical Note No: TXPM-08-01.

Uren, N. C. 2001. Types, amounts, and possible function of compounds released into the rhizosphere by soil-grown plants. Pages 19-40 in The Rhizosphere: Biochemistry and Organic Substances at the Plant-Soil Interface. Eds. Pinton, R., Z. Varanini and P. Nannipieri. Marcel Dekker, New York.

Walker, L. 2011. Fed Carbon Footprint: 121.3 Million Metric Tons; Lion's Share is DOD. Environmental Leader. http://www.environmentalleader.com/2011/05/02/fed-carbonfootprint-121-3-million-metric-tons-lion $\% \mathrm{e} \% 80 \% 99$ s-share-is-dod/

Wall, D. H., M. A. Bradford, M. G. St. John,J. A. Trofymow, V. Behan-Pelletier, D. E. Bignell, J. M. Dangerfield, W. J. Parton, J. Rusek, W. Voigt, V. Wolters, H. Z. Gardel, F. O. Ayuke, R. Bashford, O. I. Beljakova, P. J. Bohlen, A. Brauman, S. Flemming, J. R. Henschel, D. L. Johnson, T. H. Jones, M. Kovarova, J. M. Kranabetter, L. Kutny, K-C. Lin, M. Maryati, D. Masse, A. Pokarzhevskii, H. Rahman, M.G. Sabará, J-A. Salamon, M. J. Swift, A. Varela, H. L. Vasconcelos, D. White, and X. Zou. 2008. Global decomposition experiment shows soil animal impacts on decomposition are climate-dependent. Global Change Biology 14:2661-2677. doi: 10.1111/j.1365-2486.2008.01672.x.

Weiner, B. J. 2009. A theory of organizational readiness for change. Implementation Science 4(1). doi: 10.1186/1748-5908-4-67.

West, L., S. Wills, and T. Loecke. 2013. Rapid assessment of U.S. soil carbon (RaCA) for climate change and conservation planning. Summary of soil carbon stocks for the conterminous United States. Natural Resources Conservation Service, United States Department of Agriculture, Washington, DC.

White, R. E. 2006. Principles and practices of soil science: The soil as a natural resource. $4^{\text {th }}$ ed. Blackwell, Oxford, UK. 


\section{Appendix A: ORIC Evaluation}

\section{ORIC Change Valence}

Complete the sentence "People who work here....." by circling the most appropriate response for your organization.

\begin{tabular}{|c|c|c|c|c|c|}
\hline & $\begin{array}{c}1 \\
\text { Disagree }\end{array}$ & $\begin{array}{c}2 \\
\text { Somewhat } \\
\text { disagree }\end{array}$ & $\begin{array}{c}3 \\
\text { Neither agree } \\
\text { or disagree }\end{array}$ & $\begin{array}{c}4 \\
\text { Somewhat } \\
\text { agree }\end{array}$ & $\begin{array}{c}5 \\
\text { Agree }\end{array}$ \\
\hline \multirow[t]{2}{*}{1} & \multicolumn{5}{|c|}{...are committed to implementing this change. } \\
\hline & 1 & 2 & 3 & 4 & 5 \\
\hline \multirow[t]{2}{*}{2} & \multicolumn{5}{|c|}{...are determined to implement this change. } \\
\hline & 1 & 2 & 3 & 4 & 5 \\
\hline \multirow[t]{2}{*}{3} & \multicolumn{5}{|c|}{....are motivated to implement this change. } \\
\hline & 1 & 2 & 3 & 4 & 5 \\
\hline \multirow[t]{2}{*}{4} & \multicolumn{5}{|c|}{...will do whatever it takes to implement this change. } \\
\hline & 1 & 2 & 3 & 4 & 5 \\
\hline \multirow[t]{2}{*}{5} & \multicolumn{5}{|c|}{...want to implement this change } \\
\hline & 1 & 2 & 3 & 4 & 5 \\
\hline
\end{tabular}




\section{ORIC Change Efficacy}

Complete the sentence "People who work here ..." by circling the most appropriate response for your organization.

\begin{tabular}{|c|c|c|c|c|c|}
\hline & $\begin{array}{c}1 \\
\text { Disagree }\end{array}$ & $\begin{array}{c}2 \\
\text { Somewhat } \\
\text { disagree }\end{array}$ & $\begin{array}{c}3 \\
\text { Neither agree } \\
\text { or disagree }\end{array}$ & $\begin{array}{c}4 \\
\text { Somewhat } \\
\text { agree }\end{array}$ & $\begin{array}{c}5 \\
\text { Agree }\end{array}$ \\
\hline \multirow[t]{2}{*}{1} & \multicolumn{5}{|c|}{$\begin{array}{l}\text {...feel confident that they can keep the momentum going in implementing } \\
\text { this change. }\end{array}$} \\
\hline & 1 & 2 & 3 & 4 & 5 \\
\hline \multirow[t]{2}{*}{2} & \multicolumn{5}{|c|}{$\begin{array}{l}\text {...feel confident that they can manage the politics of implementing this } \\
\text { change. }\end{array}$} \\
\hline & 1 & 2 & 3 & 4 & 5 \\
\hline \multirow[t]{2}{*}{3} & \multicolumn{5}{|c|}{$\begin{array}{l}\text {...feel confident that the organization can support people as they adjust to } \\
\text { this change. }\end{array}$} \\
\hline & 1 & 2 & 3 & 4 & 5 \\
\hline \multirow[t]{2}{*}{4} & \multicolumn{5}{|c|}{$\begin{array}{l}\text {...feel confident that the organization can get people invested in } \\
\text { implementing this change. }\end{array}$} \\
\hline & 1 & 2 & 3 & 4 & 5 \\
\hline \multirow[t]{2}{*}{5} & \multicolumn{5}{|c|}{$\begin{array}{l}\text {...feel confident that they can coordinate tasks so that implementation goes } \\
\text { smoothly. }\end{array}$} \\
\hline & 1 & 2 & 3 & 4 & 5 \\
\hline \multirow[t]{2}{*}{6} & \multicolumn{5}{|c|}{$\begin{array}{l}\text {...feel confident that they can keep track of progress in implementing this } \\
\text { change. }\end{array}$} \\
\hline & 1 & 2 & 3 & 4 & 5 \\
\hline \multirow[t]{2}{*}{7} & \multicolumn{5}{|c|}{$\begin{array}{l}\text {...feel confident that they can handle the challenges that might arise in } \\
\text { implementing this change. }\end{array}$} \\
\hline & 1 & 2 & 3 & 4 & 5 \\
\hline
\end{tabular}




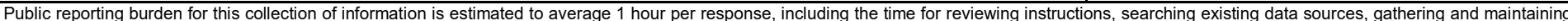

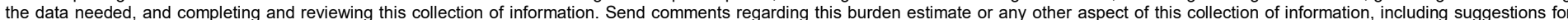

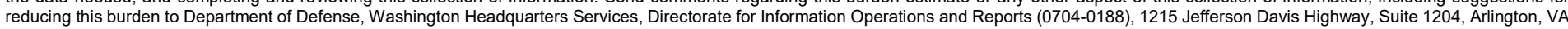

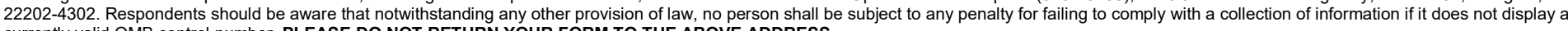
currently valid OMB control number. PLEASE DO NOT RETURN YOUR FORM TO THE ABOVE ADDRESS.
1. REPORT DATE (DD-MM-YYYY)
October 2017

\section{TITLE AND SUBTITLE}

Sustainable Carbon Dioxide Sequestration as Soil Carbon to Achieve Carbon

Neutral Status for DoD Lands

\section{DATES COVERED (From - To)}

5a. CONTRACT NUMBER

5b. GRANT NUMBER

5c. PROGRAM ELEMENT NUMBER

\section{AUTHOR(S)}

Steven L. Larson, Ryan Busby, W. Andy Martin, Victor F. Medina, Peter Seman, Christopher A. Hiemstra, Umakant Mishra and Tom Larson

5e. TASK NUMBER

5f. WORK UNIT NUMBER

33143

7. PERFORMING ORGANIZATION NAME(S) AND ADDRESS(ES)

8. PERFORMING ORGANIZATION REPORT NUMBER

U.S. Army Engineer Research and Development Center, Environmental Laboratory 3909 Halls Ferry Road, Vicksburg, MS 39180-6199

ERDC TR-17-13

9. SPONSORING / MONITORING AGENCY NAME(S) AND ADDRESS(ES)

10. SPONSOR/MONITOR'S ACRONYM(S)

Headquarters, U.S. Army Corps of Engineers

Washington, DC 20314-1000

11. SPONSOR/MONITOR'S REPORT NUMBER(S)

\section{DISTRIBUTION / AVAILABILITY STATEMENT}

Approved for public release; distribution unlimited.

\section{SUPPLEMENTARY NOTES}

\section{ABSTRACT}

Sequestration of atmospheric carbon dioxide in soils is a promising alternative for mitigation of atmospheric carbon dioxide $\left(\mathrm{CO}_{2}\right)$. The Department of Defense (DoD) owns significant land and water resources which can be managed to offset emissions. Accounting for this, sequestration could help DoD reach carbon neutrality. Many activities the DoD engages in for sustainable land management and training sustainment are conducive to soil carbon storage without even considering this as an important component; however, carbon storage could be greatly enhanced by increased understanding of optimal storage conditions and by making slight adjustments to existing practices. Land management techniques may require adjustments to maximize carbon storage while maintaining training and environmental quality. In order to achieve this, data gaps for estimating carbon fluxes need to be addressed so that accurate measurements can be taken. Unknown aspects of carbon storage as it relates to plant-soil-soil microbe interactions need to be investigated to maximize carbon storage while maintaining land use requirements. Geo-engineering concepts require further refinement to increase carbon storage in soils. These knowledge gaps are not insurmountable and could be addressed through focused research to maximize and accurately quantify carbon storage on DoD lands.

15. SUBJECT TERMS
Military bases

Carbon dioxide mitigation

Carbon sequestration
Soils-carbon content

Environmental management
16. SECURITY CLASSIFICATION OF:

REPORT

UNCLASSIFIED

ABSTRACT
UNCLASSIFIED

17. LIMITATION OF ABSTRACT
8. NUMBER OF PAGES

THIS PAGE

UNCLASSIFIED
65 19a. NAME OF RESPONSIBLE PERSON

19b. TELEPHONE NUMBER (include area code) 